\title{
Sensitivity model study of regional mercury dispersion in the atmosphere
}

\author{
Christian N. Gencarelli ${ }^{1}$, Johannes Bieser ${ }^{2,3}$, Francesco Carbone ${ }^{1}$, Francesco De Simone ${ }^{1}$, Ian M. Hedgecock ${ }^{1}$, \\ Volker Matthias $^{2}$, Oleg Travnikov ${ }^{4}$, Xin Yang $^{5}$, and Nicola Pirrone ${ }^{6}$ \\ ${ }^{1}$ CNR-Institute of Atmospheric Pollution Research, Division of Rende, Rende, Italy \\ ${ }^{2}$ Institute of Coastal Research, Helmholtz-Zentrum Geesthacht, Geesthacht, Germany \\ ${ }^{3}$ National Aeronautics and Space Center (DLR), Oberpfaffenhofen, Weßling, Germany \\ ${ }^{4}$ Meteorological Synthesizing Centre, East of EMEP, 2nd Roshchinsky proezd, 8/5, 115419 Moscow, Russia \\ ${ }^{5}$ British Antarctic Survey, Cambridge, UK \\ ${ }^{6}$ CNR-Institute of Atmospheric Pollution Research, Monterotondo, Rome, Italy \\ Correspondence to: Christian N. Gencarelli (christian.gencarelli@iia.cnr.it)
}

Received: 22 July 2016 - Published in Atmos. Chem. Phys. Discuss.: 5 August 2016

Revised: 16 December 2016 - Accepted: 16 December 2016 - Published: 13 January 2017

\begin{abstract}
Atmospheric deposition is the most important pathway by which $\mathrm{Hg}$ reaches marine ecosystems, where it can be methylated and enter the base of food chain. The deposition, transport and chemical interactions of atmospheric $\mathrm{Hg}$ have been simulated over Europe for the year 2013 in the framework of the Global Mercury Observation System (GMOS) project, performing 14 different model sensitivity tests using two high-resolution three-dimensional chemical transport models (CTMs), varying the anthropogenic emission datasets, atmospheric $\mathrm{Br}$ input fields, $\mathrm{Hg}$ oxidation schemes and modelling domain boundary condition input. Sensitivity simulation results were compared with observations from 28 monitoring sites in Europe to assess model performance and particularly to analyse the influence of anthropogenic emission speciation and the $\mathrm{Hg}_{(\mathrm{g})}^{0}$ atmospheric oxidation mechanism. The contribution of anthropogenic $\mathrm{Hg}$ emissions, their speciation and vertical distribution are crucial to the simulated concentration and deposition fields, as is also the choice of $\mathrm{Hg}_{(\mathrm{g})}^{0}$ oxidation pathway. The areas most sensitive to changes in $\mathrm{Hg}$ emission speciation and the emission vertical distribution are those near major sources, but also the Aegean and the Black seas, the English Channel, the Skagerrak Strait and the northern German coast. Considerable influence was found also evident over the Mediterranean, the North Sea and Baltic Sea and some influence is seen over continental Europe, while this difference is least over the north-western part of the modelling domain, which
\end{abstract}

includes the Norwegian Sea and Iceland. The Br oxidation pathway produces more $\mathrm{Hg}_{(\mathrm{g})}^{\mathrm{II}}$ in the lower model levels, but overall wet deposition is lower in comparison to the simulations which employ an $\mathrm{O}_{3} / \mathrm{OH}$ oxidation mechanism. The necessity to perform continuous measurements of speciated $\mathrm{Hg}$ and to investigate the local impacts of $\mathrm{Hg}$ emissions and deposition, as well as interactions dependent on land use and vegetation, forests, peat bogs, etc., is highlighted in this study.

\section{Introduction}

Mercury $(\mathrm{Hg})$ is a toxic element, present on Earth in different environmental compartments. Due to its chemical and physical properties $\mathrm{Hg}$ is a global pollutant and in its monomethyl form is hazardous to human and wildlife health. The main human methylmercury exposure pathway is through piscivorous fish consumption. Soluble inorganic $\mathrm{Hg}^{\mathrm{II}}$ compounds can be methylated in the marine environment and can enter the base of the food chain (Chen et al., 2016; Žagar et al., 2013; Oken et al., 2012; Storelli et al., 2010). Hg exists in atmosphere as gaseous elemental mercury $\left(\mathrm{GEM}, \mathrm{Hg}^{0}\right)$, reactive gaseous mercury ( $\mathrm{RGM} \mathrm{Hg}_{(\mathrm{g})}^{\mathrm{II}}$ ) and particulate bound mercury $\left(\mathrm{PBM}, \mathrm{Hg}^{(\mathrm{p})}\right)$. The term RGM describe all forms of $\mathrm{Hg}$ sampled using a $\mathrm{KCl}$-coated denuder and analysed by CVAAFS (Landis et al., 2002; Gustin et al., 2015), the exact 
chemical nature of these compounds is still not known. There is also still some debate over the oxidation and reduction mechanisms that occur in the atmosphere (Subir et al., 2011; Gustin et al., 2015). RGM is much less volatile and more water soluble than GEM, and thus it is readily transferred to aquatic and terrestrial ecosystems by dry and wet deposition processes. Moreover, GEM concentrations in some regions are linked to large-scale climatological phenomena (Carbone et al., 2016).

Since European $\mathrm{Hg}$ riverine discharges have been reduced greatly since the 1970s, atmospheric deposition has become the most important source of $\mathrm{Hg}$ in the marine ecosystems.

In order to support the recent Minamata convention (http: //www.mercuryconvention.org/), the GMOS (Global Mercury Observation System, http://www.gmos.eu/) project has set up a global Hg observation network, with the aim to work alongside existing networks for Europe, USA and Asia. The data obtained by GMOS have made it possible to fill in some of the gaps left by regional networks, by performing measurements in places which have until now not been studied, especially in the Southern Hemisphere. In Europe the GMOS network has complemented the EMEP regional network with special measurements, such as the Med-Oceanor oceanographic campaigns in the Mediterranean marine boundary layer (MBL; Gencarelli et al., 2014b; Sprovieri et al., 2010), the ETMEP (European Tropospheric Mercury Experiment) series of tropospheric measurements (Weigelt et al., 2016) and the fixed station at Longobucco, in the south of Italy (Sprovieri et al., 2016b). This station is currently the southernmost in Europe and is in the centre of the Mediterranean Sea region. Compared to the north of Europe, however, southern and eastern Europe still lack monitoring stations. Within GMOS global chemical transport models (CTMs) have been used to evaluate the intercontinental transport of anthropogenic Hg (De Simone et al., 2016) and analyse different future $\mathrm{Hg}$ emission scenarios (Pacyna et al., 2016), source-receptor relationships (Travnikov et al., 2010) and $\mathrm{Hg}$ cycles in the polar regions (Angot et al., 2016). Regionalscale models have been used for a closer study of the processes that occur in specific areas at much higher spatial resolution than the global CTMs (Gencarelli et al., 2015; Bieser et al., 2014). In a recent review Ariya et al. (2015) give a exhaustive summary of modelling progress and of the uncertainties still present concerning the atmospheric $\mathrm{Hg}$ cycle. To date only a limited number of model-to-model intercomparisons have been carried out (for the US: Bullock et al., 2008, 2009; Zhang et al., 2012; for Europe: Ryaboshapko et al., 2007; for global models: Travnikov et al., 2010, 2016; AMAP/UNEP, 2013), where it was found that are often significant differences in $\mathrm{Hg}$ concentrations and deposition estimated by different models. Previous European studies (Ryaboshapko et al., 2007) performed a model intercomparison for the year 1999, using eight different models and data from 11 measurement stations with the aim to characterise the ability of CTMs to predict atmospheric $\mathrm{Hg}$ concentration and deposition fields.

The aim of this work is to analyse the influence of different processes affecting atmospheric $\mathrm{Hg}$ and quantify some of the uncertainties present in the regional $\mathrm{Hg}$ cycle (highlighted in the aforementioned model comparisons), in particular anthropogenic emission speciation and the $\mathrm{Hg}_{(\mathrm{g})}^{0}$ atmospheric oxidation mechanism. The atmospheric $\mathrm{Hg}$ cycle has been simulated over Europe for the year 2013, performing 14 different model sensitivity tests using the WRF/Chem-Hg model for the most part. A number of further investigations were also performed using the CMAQ-Hg model, to gain an insight into model-to-model variation. The model sensitivity tests were conducted using different anthropogenic emission datasets, $\mathrm{Br}$ concentration input fields, $\mathrm{Hg}$ oxidation schemes and global CTMs to provide boundary condition input. The experimental results were compared with observations from 28 monitoring sites in Europe ( 23 from the EMEP network, 4 from the EMEP/GMOS network including the Longobucco station of the GMOS network), in order to validate model performance and investigate the influences of anthropogenic emission speciation and the $\mathrm{Hg}_{(\mathrm{g})}^{0}$ atmospheric oxidation mechanism. A more detailed screening for some selected stations was performed in order to investigate some anomalies in the sensitivity model results.

The work presented here was performed in the framework of the GMOS Mercury Modelling Task Force (MMTF; Travnikov et al., 2016).

\section{Methods}

\subsection{Models description and set-up}

Both models used in this analysis use a Lambert conformal model domain covering Europe and the Mediterranean Sea, including part of the western North Atlantic Ocean, North Africa and the Middle East (see Fig. 1), with a horizontal resolution of $24 \times 24 \mathrm{~km}$ and 30 vertical levels. The online WRF/Chem-Hg model (Gencarelli et al., 2014a) is a modified version of the WRF/Chem model (version 3.4; Grell et al., 2005), which includes emissions, transport, atmospheric chemistry and deposition of $\mathrm{Hg}$.

The Hg emissions in the model include online GEM evasion from the sea surface (based on the parametrisation of Wanninkhof, 1992, and the methodology of Gårdfeldt et al., 2003, with dissolved gaseous mercury concentrations of $150 \mathrm{fmol} \mathrm{L}^{-1}$ ) and anthropogenic emissions from the AMAP (AMAP/UNEP, 2013) and EDGAR (Muntean et al., 2014) inventories (see Sect. 2.2). The gas-phase chemistry of $\mathrm{Hg}$ and a parametrised representation of atmospheric $\mathrm{Hg}$ aqueous chemistry have been added to the RADM2 chemical mechanism using KPP (Sandu and Sander, 2006) and the WKC coupler (Salzmann and Lawrence, 2006), while the atmospheric physics and transport are solved by the WRF 


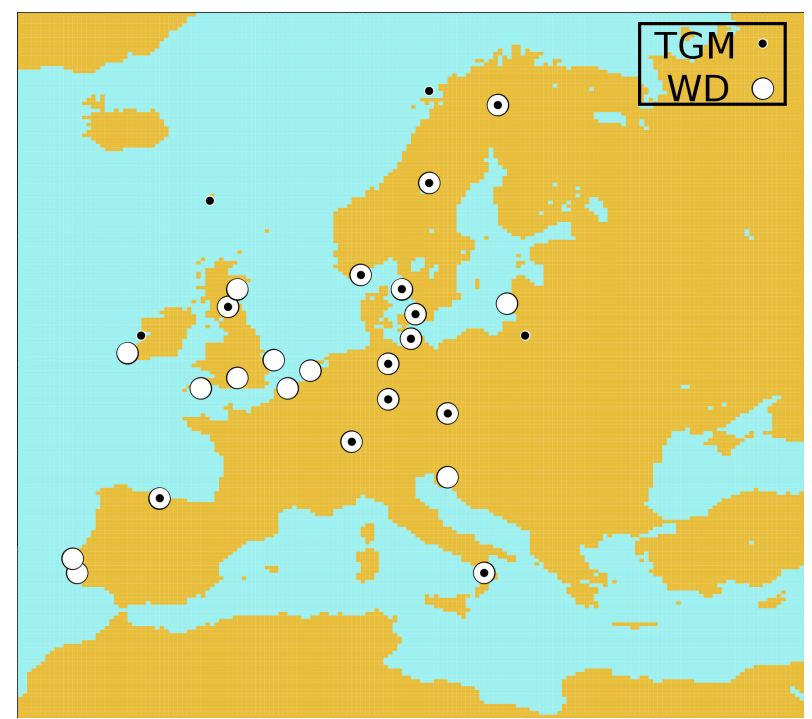

Figure 1. The model domain and location to the measurement stations (white points for wet deposition (WD) and black points for TGM air concentrations).

model core using the parametrisations described in Gencarelli et al. (2014a). Hg dry deposition is treated according to the approach developed by Wesely (1989) and calculated as described in Lin et al. (2006). Wet deposition (in-cloud and below-cloud scavenging) of $\mathrm{Hg}$ species has been implemented by adapting an already available module in WRF/Chem, based on the approach described by Neu and Prather (2012). Chemical initial and boundary conditions (IC/BC) were taken from the ECHMERIT model (Jung et al., 2009; De Simone et al., 2014, 2015, 2016) for Hg species, while boundary conditions for other chemical species were taken from MOZART-4 (Emmons et al., 2010).

The second model used is CMAQ-Hg (version 5.0.1), based on CMAQ (Byun and Ching, 1999) and modified by Bullock and Brehme (2002) and Gbor et al. (2006) to include chemistry, transport and deposition of GEM, gaseous oxidized mercury (GOM) and PBM. This model was compiled with the multi-pollutant version of the CBM5 photochemical mechanism (Sarwar et al., 2008) (which includes $\mathrm{Hg}$ gaseous reactions with $\mathrm{O}_{3}, \mathrm{OH}, \mathrm{H}_{2} \mathrm{O}_{2}$ and $\mathrm{Cl}_{2}$ as described by Lin and Tao, 2003) with the Euler backward iterative solver and the AERO4 aerosol mechanism (Binkowski and Roselle, 2003). The CMAQ-Hg model uses offline meteorological fields provided by the COSMO-CLM model (Rockel et al., 2008), processed by the Meteorology-Chemistry Interface Processor (MCIP v3.6). The same MCIP is used to calculate the dry deposition velocities of GEM and GOM. During the offline simulations cloud processes, including cloud attenuation of photolysis rates, convective and nonconvective mixing and scavenging by clouds, aqueous-phase chemistry and wet deposition were calculated as described in Liu and Zhang (2013). The chemical IC/BC were taken from the GLEMOS model (Travnikov et al., 2009). For further details on the models see Gencarelli et al. (2014a, 2015) for WRF/Chem-Hg and Bieser et al. (2014) and Zhu et al. (2015) for CMAQ-Hg.

The main difference between the two models is in the feedback between chemical and meteorological dynamics: while in CMAQ the meteorological fields are provided as input (offline model), in WRF they are solved simultaneously with the chemistry, in the same time step (online model). Other major differences concern the parametrisations of some of the processes, for instance GEM dry deposition, convective precipitation and GEM evasion from the sea surface (see Gencarelli et al., 2015, and Bieser et al., 2014, for details). Other differences result from the use of different $\mathrm{BC}$ sets and meteorological input.

Oxidation of $\mathrm{Hg}$ by bromine was implemented in some of the WRF experiments, using the offline $\mathrm{Br}$ fields obtained from the p-TOMCAT (Yang et al., 2005, 2010) and GEOSCHEM (Parrella et al., 2012) models.

\subsection{Modelled emissions}

In order to analyse the effects of anthropogenic emission speciation, amount and vertical distribution, the input from the two recent global anthropogenic $\mathrm{Hg}$ emission inventories was interpolated over the model grids and used in the sensitivity simulations.

The AMAP/UNEP 2010 (hereafter AMAP) inventory is available at a spatial resolution of $0.5^{\circ}$ by $0.5^{\circ}$ (AMAP/UNEP, 2013), while the EDGARv4.tox 12008 (hereafter EDGAR) has a spatial resolution of $0.1^{\circ}$ by $0.1^{\circ}$ (Muntean et al., 2014). Over the modelling domain the inventories differ in both emission totals and speciation ratio GEM : RGM : PBM as

- $136.2 \mathrm{Mg} \mathrm{yr}^{-1}$ with GEM : RGM : PBM ratio $65: 28: 7$ for AMAP and

- $123.8 \mathrm{Mg} \mathrm{yr}^{-1}$ with $60: 32: 8$ for EDGAR.

They also have different emission height distributions: AMAP uses three height classes $(0-50,50-150$ and above $150 \mathrm{~m}$ ) whereas EDGAR ranges into six classes (distributed between 0 and $800 \mathrm{~m}$, listed according with SNAP, Selected Nomenclature for Air Pollution, categories as used in De Simone et al., 2016). The differences in the geographical distributions are shown in Fig. 2.

\subsection{Simulations performed}

Simulations were performed varying the emission speciation, the atmospheric $\mathrm{Hg}$ oxidation mechanism, the bromine concentration field and the atmospheric process parametrisation. A total of 14 (9 with WRF and 5 with CMAQ) 12-month model simulations were conducted, as reported in Table 1, where experiments conducted using CMAQ are indicated by 
Table 1. Simulations performed.

\begin{tabular}{|c|c|c|c|c|}
\hline Experiment & CTM & $\mathrm{BC}$ & $\begin{array}{l}\text { Anthropogenic } \\
\text { emissions }\end{array}$ & Description \\
\hline BASE & WRF/Chem-Hg & ECHMERIT & AMAP & Base experiment, performed as in Gencarelli et al. (2015) \\
\hline ANTSPEC & WRF/Chem-Hg & ECHMERIT & AMAP & RGM and PBM emissions as GEM \\
\hline NOANT & WRF/Chem-Hg & ECHMERIT & AMAP & No Hg anthropogenic emissions \\
\hline NOCHEM & WRF/Chem-Hg & ECHMERIT & AMAP & No $\mathrm{Hg}$ chemical reactions \\
\hline O3CHEM & WRF/Chem-Hg & ECHMERIT & AMAP & As ANTSPEC, but with only $\mathrm{O}_{3}$ GEM oxidation (Hall, 1995) \\
\hline OHCHEM & WRF/Chem-Hg & ECHMERIT & AMAP & $\begin{array}{l}\text { As ANTSPEC, but with only OH GEM oxidation (Sommar } \\
\text { et al., 2001) }\end{array}$ \\
\hline BASE2 & WRF/Chem-Hg & ECHMERIT & EDGAR & $\begin{array}{l}\text { As BASE, but with anthropogenic emissions from EDGAR } \\
\text { inventory }\end{array}$ \\
\hline BRCHEM1 & WRF/Chem-Hg & ECHMERIT & AMAP & $\begin{array}{l}\text { As ANTSPEC, but with only Br two step GEM oxidation, } \\
\text { Br from p-TOMCAT }\end{array}$ \\
\hline BRCHEM2 & WRF/Chem-Hg & ECHMERIT & AMAP & As BRCHEM1, but with Br input from GEOS-Chem model \\
\hline BASE $_{\mathrm{C}}$ & CMAQ-Hg & GLEMOS & AMAP & Base CMAQ experiment \\
\hline ANTSPEC $_{\mathrm{C}}$ & CMAQ-Hg & GLEMOS & AMAP & RGM and PBM emissions as GEM \\
\hline NOCHEM $_{C}$ & CMAQ-Hg & GLEMOS & AMAP & No $\mathrm{Hg}$ chemical reactions \\
\hline $\mathrm{O}_{3} \mathrm{CHEM}_{\mathrm{C}}$ & CMAQ-Hg & GLEMOS & AMAP & As ANTSPEC $C$, but with only $\mathrm{O}_{3}$ GEM oxidation \\
\hline $\mathrm{OHCHEM}_{\mathrm{C}}$ & CMAQ-Hg & GLEMOS & AMAP & As ANTSPEC $_{C}$, but with only OH GEM oxidation \\
\hline
\end{tabular}

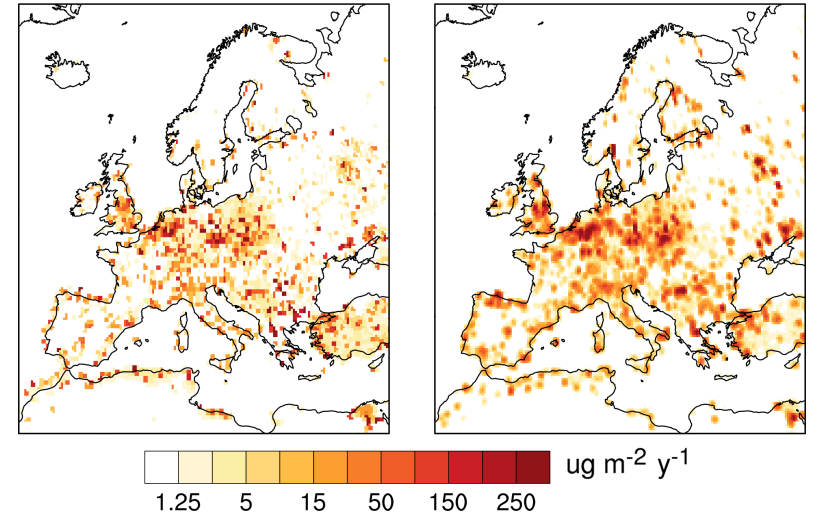

Figure 2. The anthropogenic $\mathrm{Hg}$ emissions used in the model experiments: AMAP (left panel) and EDGAR (right panel).

a C subscript. The specific scopes of every particular experiment were as follows:

- BASE is the base case test, used as the reference experiment. It refers to the model in the standard configuration, with AMAP anthropogenic emissions and $\mathrm{Hg}$ oxidation driven only by $\mathrm{O}_{3}$ and $\mathrm{OH}$ for WRF/Chem$\mathrm{Hg}$ and by $\mathrm{O}_{3}, \mathrm{OH}, \mathrm{H}_{2} \mathrm{O}_{2}$ and $\mathrm{Cl}_{2}$ for CMAQ- $\mathrm{Hg}$, as described in Sect. 2.1.

- BASE2 is similar to BASE experiment, but with Hg anthropogenic emission used. In fact in this case EDGAR $\mathrm{Hg}$ emissions are used.

- NOANT is the hypothetical scenario in which all anthropogenic emissions are turned off in order to highlight the influence of long-range transport on European areas. The same chemical mechanism of BASE experiment is used.

- NOCHEM is the hypothetical scenario in which the chemical reactions of $\mathrm{Hg}$ are turned off. In this way there is no conversion of GEM in RGM, which implies a different distribution of $\mathrm{Hg}$ deposition with respect to the BASE experiment.

- ANTSPEC is the hypothetical experiment in which all $\mathrm{Hg}$ emissions are treated as GEM. With this experiment RGM and PBM emissions are turned off; by considering the different chemical and physical properties with respect to the GEM, the deposition can occur in a location far from the emission points. It would represent a lower bound on deposition from local anthropogenic sources and an upper bound on long-range transport of anthropogenic emissions because GEM has a much longer lifetime against deposition than RGM and PBM.

- O3CHEM, OHCHEM, BRCHEM1 and BRCHEM2 are the hypothetical experiments in which only a singular reaction of $\mathrm{Hg}$ atmospheric was active (only $\mathrm{O}_{3}, \mathrm{OH}$ or $\mathrm{Br}$, respectively). The $\mathrm{HgBr}+\mathrm{OH}$ rate constant is taken from the assumptions made in Holmes et al. (2010). These sensitivity tests are not a direct comparison between the chemical mechanisms, but they are an analysis of how much the atmospheric system changes considering a singular $\mathrm{Hg}$ oxidant. The difference between the BRCHEM1 and BRCHEM2 simulations shows how $\mathrm{Hg}$ responds to the different atmospheric $\mathrm{Br}$ concentration fields. 
A summary of the simulations performed is shown in Table 1 . Some of these tests have been studied for other regions (e.g. Travnikov et al., 2016 and Bieser et al., 2016) while many other studies have investigated $\mathrm{Hg}$ oxidation by ozone or Br (Hynes et al., 2009; Subir et al., 2011, 2012; WeissPenzias et al., 2015).

\subsection{Measurement networks}

Model results have been compared with observations of total gaseous mercury (TGM, $\mathrm{Hg}_{(\mathrm{g})}^{\mathrm{O}}+\mathrm{Hg}_{(\mathrm{g})}^{\mathrm{II}}$ ) and $\mathrm{Hg}$ wet deposition from 28 EMEP and GMOS measurement sites as shown in Table 2. Of these, 13 measured both TGM air concentrations and $\mathrm{Hg}$ in precipitation, 4 measured only TGM and 11 only $\mathrm{Hg}$ in precipitation (Fig. 1). A comparison was made between monthly averaged values of TGM observations and monthly $\mathrm{Hg}$ in precipitation (Aas and Bohlin-Nizzetto, 2015; D'Amore et al., 2015). Monthly averages were used because the measurement frequency was not the same at all the sites.

\section{Results}

The principal differences between the models used concern the parametrisations of some of the processes, for instance GEM dry deposition, convective precipitation and GEM evasion from the sea surface (see Gencarelli et al., 2015, and Bieser et al., 2014, for details). Other differences result from the use of different BC sets and meteorological input. Despite these differences, the base cases (BASE and BASE ${ }_{C}$ ) give similar $\mathrm{Hg}$ deposition totals of $219 \mathrm{Mg} \mathrm{yr}^{-1}$ in the WRF BASE and $208 \mathrm{Mg} \mathrm{yr}^{-1}$ in the CMAQ BASE $\mathrm{C}_{\mathrm{C}}$ experiments (Table 3). The differences in deposition parametrisations do have an effect on the ratio of dry to wet $\mathrm{Hg}$ deposition, however. While dry and wet deposition are almost equal in the WRF simulations (wet $49 \%$, dry $51 \%$ ), the dry deposition in CMAQ is more than twice the wet $(69 \%$ dry and $31 \%$ wet); see Table 3 and Figs. 3 and 4 for details. There are major differences in the spatial distribution of the Hg deposition: wet deposition in WRF is greater over continental Europe, the North Sea and around Iceland, while in CMAQ deposition is highest over the Alps and along the Balkan coast. Although both models simulate higher dry deposition over land than the sea the distribution in CMAQ is more even than that simulated by WRF, which has quite distinct regions and hot spots of high deposition (Fig. 3).

\subsection{Modelled and Observed Hg species comparison}

The skill of the WRF/Chem-Hg and CMAQ-Hg model in reproducing the modelled $\mathrm{Hg}$ concentrations, deposition fluxes and precipitation fields has been described in previous studies (see Gencarelli et al., 2015; Bieser et al., 2014, and references therein). Thus, the principal aim of this study is to analyse the performance of models in terms of validation of the sensitivity tests, also comparing the results of all the sim-
Table 2. List of observation points.

\begin{tabular}{lllcc}
\hline CODE & Name & Network & TGM & WD \\
\hline BE14 & Koksijde & EMEP & & $\bullet$ \\
CZ03 & Košetice & EMEP & $\bullet$ & $\bullet$ \\
DE02 & Waldhof & EMEP & $\bullet$ & $\bullet$ \\
DE03 & Schauinsland & EMEP & $\bullet$ & $\bullet$ \\
DE08 & Schmücke & EMEP & $\bullet$ & $\bullet$ \\
DE09 & Zingst & EMEP & $\bullet$ & $\bullet$ \\
DK01 & Færøerne & EMEP & $\bullet$ & \\
ES08 & Niembro & EMEP & $\bullet$ & $\bullet$ \\
FI36 & Pallas & EMEP/GMOS & $\bullet$ & $\bullet$ \\
GB13 & Yarner Wood & EMEP & & $\bullet$ \\
GB17 & Heigham Holmes & EMEP & & $\bullet$ \\
GB36 & Harwell & EMEP & & $\bullet$ \\
GB48 & Auchencorth Moss & EMEP & $\bullet$ & $\bullet$ \\
GB91 & Banchory & EMEP & & $\bullet$ \\
IE01 & Valentia Obs. & EMEP & & $\bullet$ \\
IE31 & Mace Head & EMEP/GMOS & $\bullet$ & \\
LV01 & Rucava & EMEP & & $\bullet$ \\
NL91 & De Zilk & EMEP & & $\bullet$ \\
NO01 & Birkenes & EMEP & $\bullet$ & $\bullet$ \\
NO90 & Andoya & EMEP & $\bullet$ & \\
PL05 & Diabla Gora & EMEP & $\bullet$ & \\
PT04 & Monte Velho & EMEP & & $\bullet$ \\
PT06 & Alfragide & EMEP & & $\bullet$ \\
SE05 & Bredkalen & EMEP & $\bullet$ & $\bullet$ \\
SI08 & Iskrba & EMEP/GMOS & & $\bullet$ \\
SE11 & Vavihill & EMEP & $\bullet$ & $\bullet$ \\
SE14 & Råö & EMEP/GMOS & $\bullet$ & $\bullet$ \\
LONG & Longobucco & GMOS & $\bullet$ & $\bullet$ \\
\hline & & & &
\end{tabular}

Table 3. Wet and dry annual deposition (Mg).

\begin{tabular}{lrrr}
\hline Experiment & Wet & Dry & Total \\
\hline BASE & 108.0 & 111.0 & 219.0 \\
ANTSPEC & 88.0 & 32.0 & 120.0 \\
NOANT & 52.1 & 19.2 & 71.3 \\
NOCHEM & 26.5 & 81.4 & 107.9 \\
O3CHEM & 38.5 & 13.9 & 52.4 \\
OHCHEM & 27.8 & 14.3 & 42.1 \\
BASE2 & 94.4 & 79.9 & 174.3 \\
BRCHEM1 & 63.2 & 33.2 & 96.4 \\
BRCHEM2 & 60.2 & 32.0 & 92.2 \\
BASE $_{C}$ & 65.5 & 142.7 & 208.2 \\
ANTSPEC $_{C}$ & 56.5 & 105.7 & 162.2 \\
O3CHEM $_{C}$ & 52.2 & 99.1 & 151.3 \\
OHCHEM $_{C}$ & 50.5 & 98.9 & 98.9 \\
NOCHEM $_{C}$ & 21.2 & 65.2 & 86.4 \\
\hline
\end{tabular}

ulations performed with the available observations reported in Sect. 2.4.

Generally for GEM atmospheric concentrations there is a general underestimation in the WRF model simulations and an overestimation in CMAQ model simulations. For wet deposition values the CMAQ model tends to overestimate the 


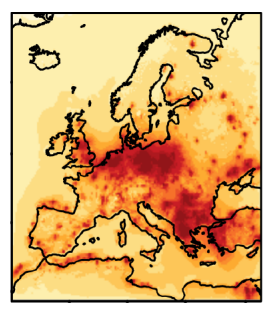

BASE

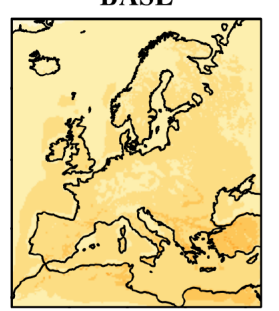

ANTSPEC

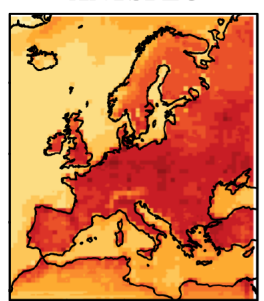

BASE $_{\mathbf{C}}$

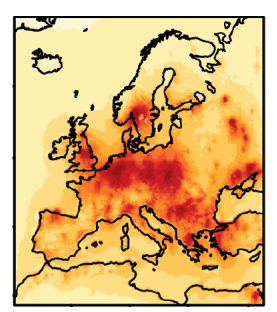

BASE2

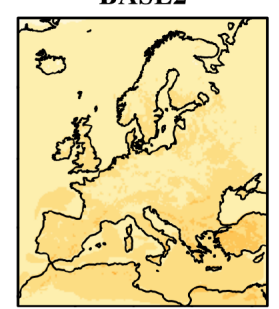

O3CHEM

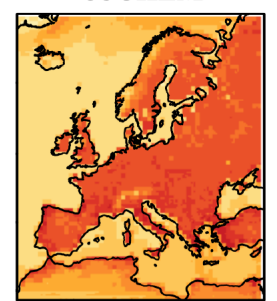

ANTSPEC $_{C}$

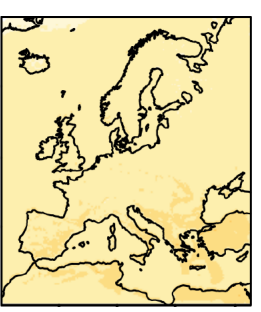

NOANT

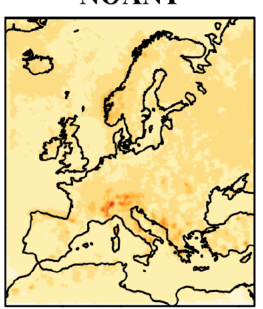

OHCHEM

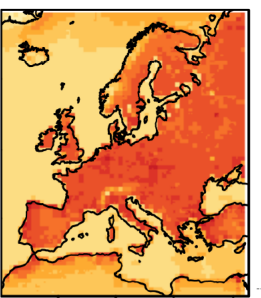

O3CHEM $_{C}$

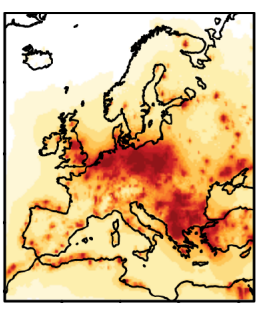

NOCHEM

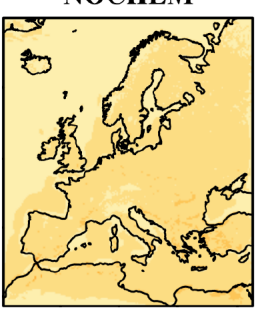

BRCHEM1

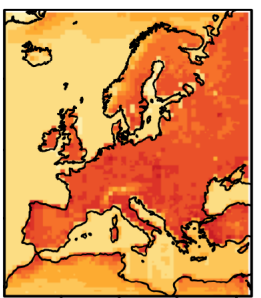

OHCHEM $_{\mathrm{C}}$

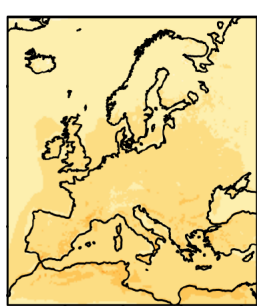

BRCHEM2

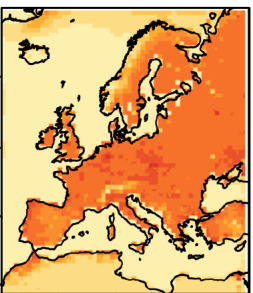

NOCHEM $_{\mathrm{C}}$

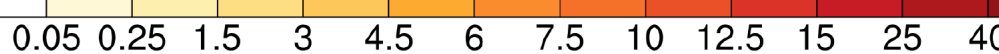

Figure 3. The total $\mathrm{Hg}$ dry deposition in the model experiments performed.

observations, especially in Scandinavia, England and at Longobucco. In contrast, the WRF model has different characteristics: in Scandinavia the observations are always overestimated when compared to the rest of the domain, in the BASE2 experiment the greatest overestimation occurs while in the ANTSPEC experiment there is a general underestimation almost everywhere (given the lack of RGM emissions it is not surprising that the deposition is lower in this experiment).

Overall the comparison between base model (BASE, ANTSPEC, BASE $C$, ANTSPEC $C$ and BASE2) results and observations obtained (both for TGM concentrations and $\mathrm{Hg}$ in wet deposition) at all stations is broadly in agreement with previous studies (e.g. Ryaboshapko et al., 2007). Comparing modelled and observed values of TGM concentrations, the ratio of annual model-observation pairs is within $30 \%$ in almost all stations for the BASE, ANTSPEC, BASE ${ }_{C}$, ANTSPEC $_{C}$ and BASE2 experiments, while an obvious underestimation occurs in NOANT experiment (Fig. 5a). It is, however, interesting to look at cases where the model-toobservation ratio is different in order to highlight the differences which are found in the sensitivity tests and in different locations. In the central, DE03 (Schauinsland), and southern, DE08 (Schmücke), German stations, the BASE and BASE2 experiments underestimate the observed annual average TGM concentration by 1.75 and $1.65 \mathrm{ng} \mathrm{m}^{-3}$ respectively, while the ANTSPEC experiment shows better agreement. Contrarily, the relatively nearby station at Košetice (CZ03, a rural location in the Czech Republic) the TGM concentrations are overestimated in the ANTSPEC experiment, while the BASE and BASE2 simulations show good agreement. In this station an annual average of $1.24 \mathrm{ng} \mathrm{m}^{-3}$ was observed.

The DE03, DE08 and CZ03 sites are the most central European continental sites with available observations and are characterised by an elevated contribution from local $\mathrm{Hg}$ emissions with respect to the contribution from long-range transport (Gencarelli et al., 2015). In Gencarelli et al. (2015) local sources are those within the domain, including anthropogenic emissions and evasion from the sea surface, while long-range sources are those from the boundary conditions obtained from the global model. The strongest influence of local emissions was found at the CZ03 station, as suggested by the large overestimation of GEM concentrations in the ANTSPEC experiment $(\simeq 37 \%$, which instead was not the case in the BASE experiment). 


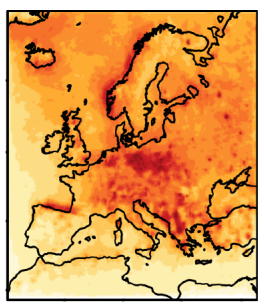

BASE

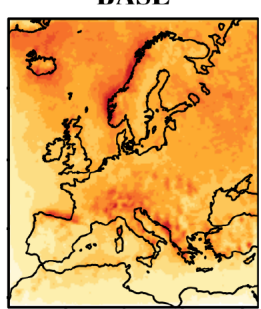

ANTSPEC

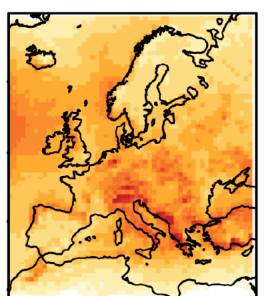

BASE $_{C}$

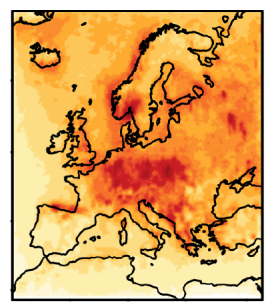

BASE2

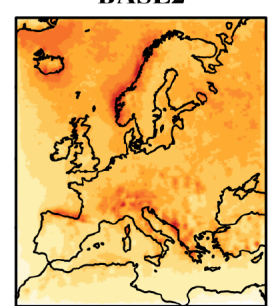

OЗСHEM

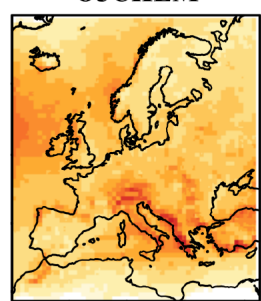

ANTSPEC $_{C}$

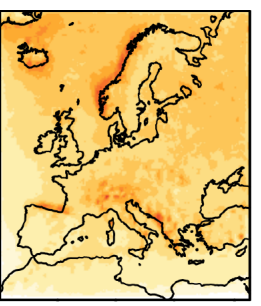

NOANT

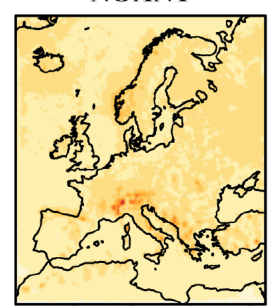

OHCHEM

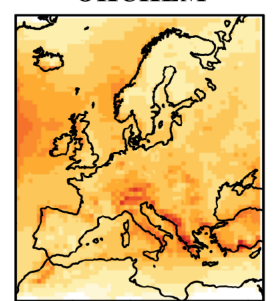

O3CHEM $_{C}$

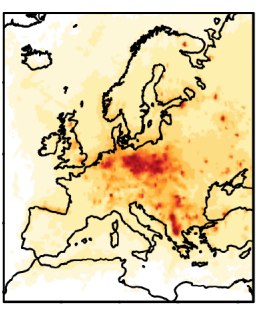

NOCHEM

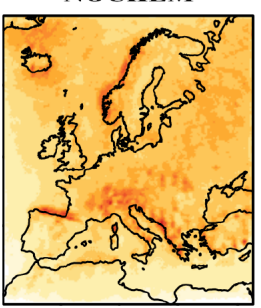

BRCHEM1

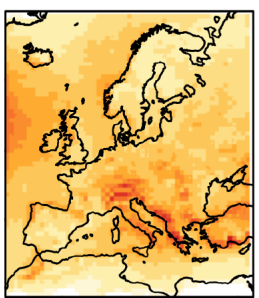

OHCHEM $_{C}$

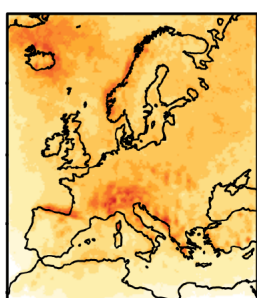

BRCHEM2

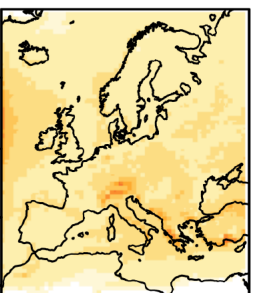

NOCHEM $_{\mathrm{C}}$

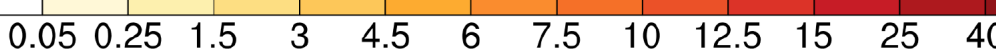

Figure 4. The total $\mathrm{Hg}$ wet deposition in the model experiments performed.

This is due to the emissions from chloralkali plants, which are still important sources in some parts of central Europe (Wang et al., 2012), while the different behaviour seen at DE03 and DE08 is most likely due to a local emission process or processes, possibly of non-anthropogenic origin as argued in Siudek et al. (2016) for a study of forested Polish sites. The German sites used in this study are in mountainous and hilly forested regions (DE03 in the Black Forest - 1205 ma.s.l. - and DE08 in the Thuringian Forest 937 m a.s.l.) are the two sites where the model underestimation is greatest.

At the GB48 station (Auchencorth Moss) and the coastal site of Niembo, ES08, the models fail to reproduce the low annual average TGM concentrations of 0.89 and $0.46 \mathrm{ng} \mathrm{m}^{-3}$ respectively. At the GB48 site the disagreement between the models and observations can be attributed to local effects, as suggested by Drewer et al. (2010) in their study of greenhouse gas fluxes at the site. In fact this site is located in a peat bog, and the observed TGM values are very different from sites at similar latitudes such as DK01, Færøerne, and IE31, Mace Head, where the annual average TGM concentrations were 1.56 and $1.49 \mathrm{ng} \mathrm{m}^{-3}$, respectively, and the models are able to reproduce the observations.
Overall the overestimation of GEM concentrations using WRF/Chem-Hg is greater in the OHCHEM experiment due to a lower rate of $\mathrm{Hg}_{(\mathrm{g})}^{0}$ oxidation and lower in NOANT because there are no anthropogenic emissions.

The monthly comparison between the observed and modelled concentrations are shown in Figs. 6a and 7a (only the principal experiments are shown). There is a clear overestimation of monthly concentrations by CMAQ, particularly during summer. Only small differences occur changing the anthropogenic emission inventory (BASE2), while the differences when the speciation (ANTSPEC) and the chemical mechanism (BRCHEM1) are changed and are much more evident. Decreasing the uncertainty in flue gas speciation would be a great advantage in modelling the atmospheric $\mathrm{Hg}$ cycle.

Comparing modelled and observed values of wet deposition fluxes gives a ratio of annual model-observation pairs within a factor of 2 in most stations ( 15 of the 24 stations), while in 23 of the 24 stations it is within a factor of 5 (see Fig. 5b). The outlier is the Valentia Observatory (IE01) in south-west Ireland: the annually averaged observed $\mathrm{Hg}$ deposition is $1.70 \mu \mathrm{g} \mathrm{m}^{-2}$ month $^{-1}$, which is high with respect to the median of $0.31 \mu \mathrm{g} \mathrm{m}^{-2}$ month $^{-1}$ and the average of 

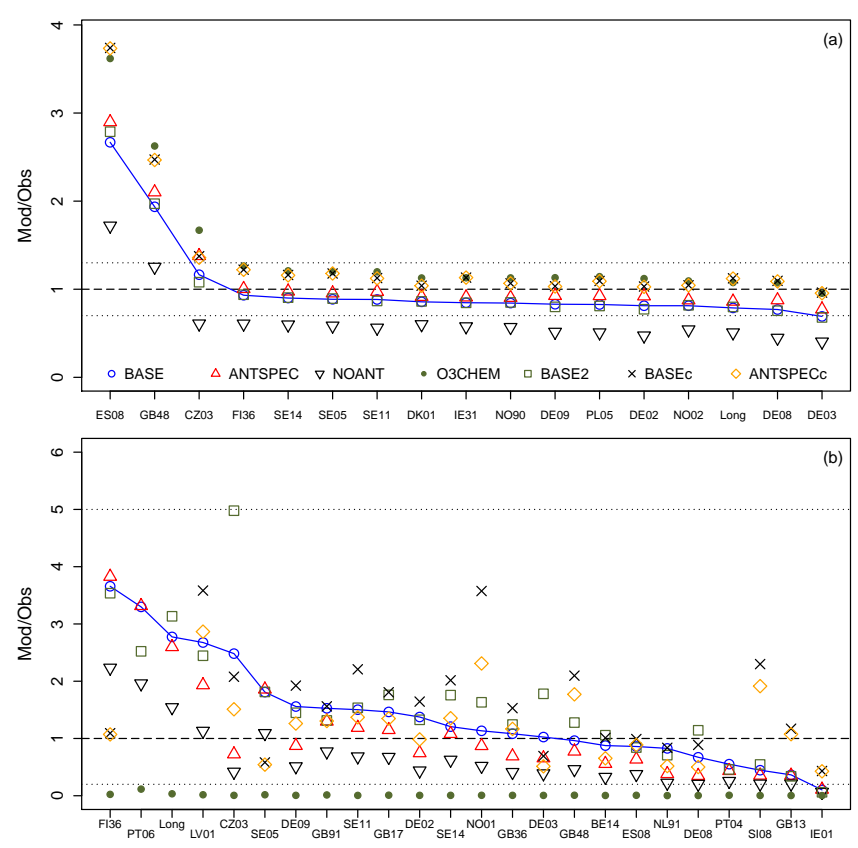

Figure 5. Ratio of the modelled and observed values at the measurement station points. (a)GEM concentrations; (b) wet deposition fluxes. Horizontal lines represent perfect agreement (dashed line, ratio $=1$ ) and good agreement intervals (dotted lines, $\pm 30 \%$ for GEM, factor 5 for WD).

$0.46 \mu \mathrm{g} \mathrm{m}^{-2}$ month $^{-1}$ in all stations $\left(1.70 \mu \mathrm{g} \mathrm{m}^{-2}\right.$ month $^{-1}$ is approximately the 97 th percentile). Moreover, the underestimation is more notable in WRF (ratio $\simeq 0.10$ ) than CMAQ $(\simeq 0.40)$.

Overall in the BASE and ANTSPEC experiment slight overestimates were found, while the results from CMAQ experiments show higher $\mathrm{Hg}$ wet deposition fluxes than in the WRF/Chem-Hg experiments. In Sprovieri et al. (2016a) high values of wet deposition in Råö (SE14) and Pallas (FI36) stations were found, compared to the other European stations in the GMOS network. The model results reflect this result, with high deposition fluxes in the north of Europe. In these stations, as in all of Scandinavia, the oxidation mechanism makes a great difference; see the BRCHEM1 and BRCHEM2 experiments.

\subsection{Emission speciation}

Recently, in order to study the impact of $\mathrm{Hg}$ anthropogenic emission speciation on $\mathrm{Hg}$ deposition and its global cycle, some modelling studies have made use of modified anthropogenic emission inventories, either in terms of emission totals or in terms of the emission speciation (Selin et al., 2008; Amos et al., 2012; Horowitz et al., 2014). For example, Bieser et al. (2014) (for Germany) and Kos et al. (2013) (for the US) obtain the best agreements between observations and model results when assuming no RGM emissions and using a modified emission speciation ratio of $90: 8: 2$ instead

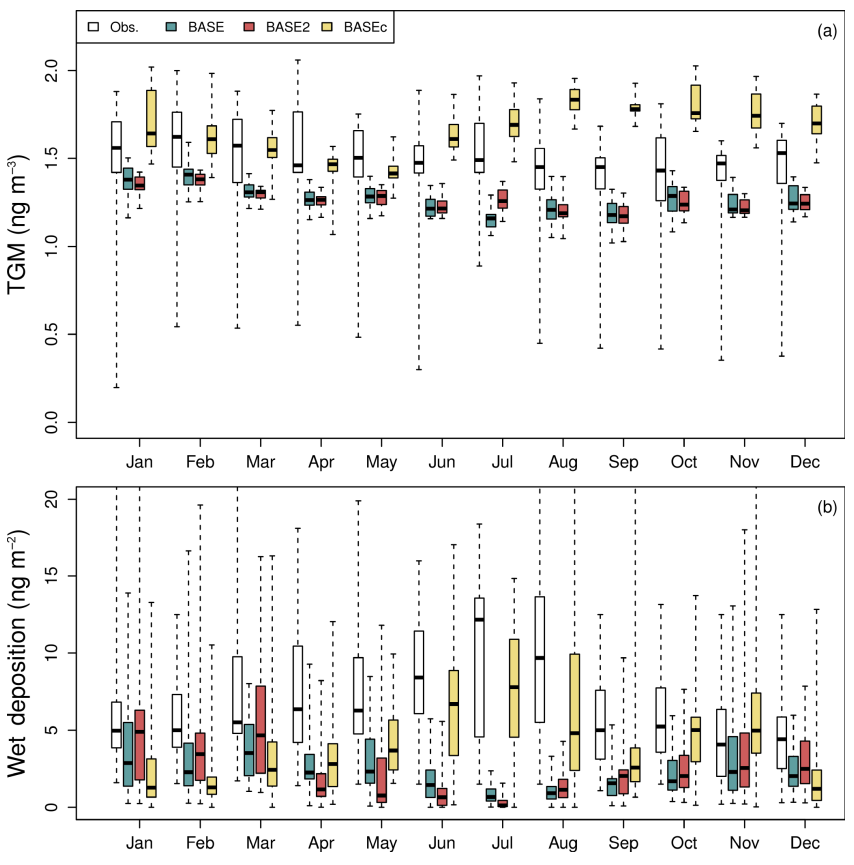

Figure 6. Monthly distribution of observed and modelled values for BASE, BASE2 and BASE $\mathrm{C}_{\mathrm{C}}$ experiments at measurement stations. (a) TGM concentrations; (b) wet deposition fluxes.
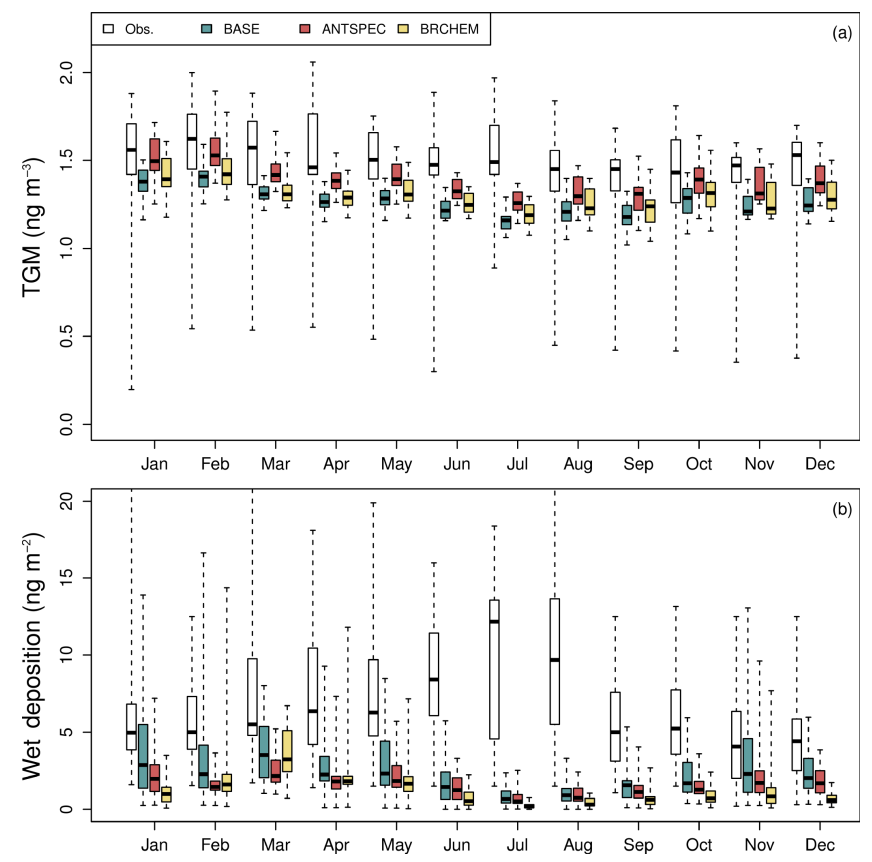

Figure 7. Monthly distribution of observed and modelled values for BASE, ANTSPEC and BRCHEM1 experiments at measurement stations. (a) TGM concentrations; (b) wet deposition fluxes. 


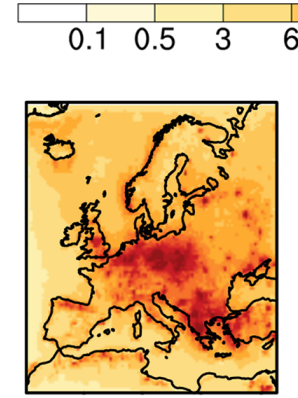

BASE

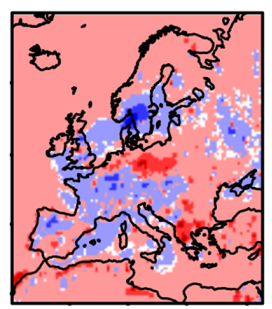

BASE2

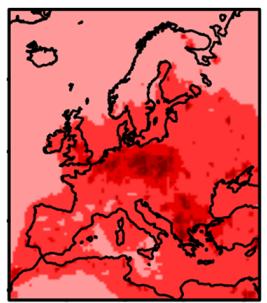

NOANT

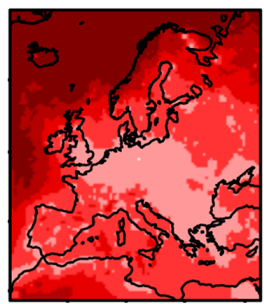

NOCHEM

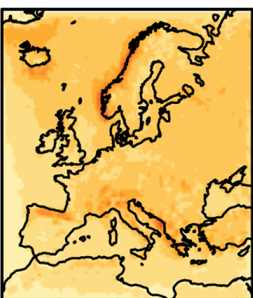

ANTSPEC

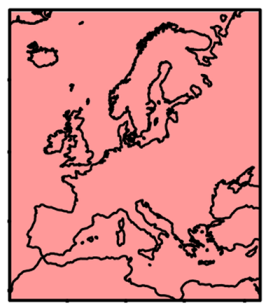

O3CHEM

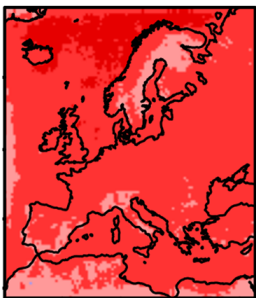

OHCHEM

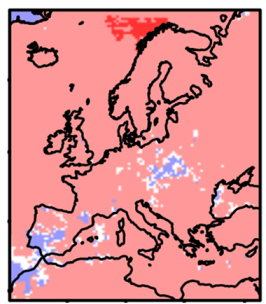

BRCHEM1

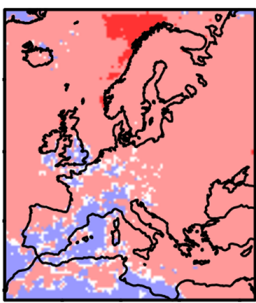

BRCHEM2

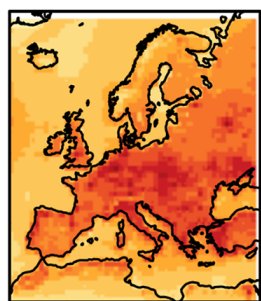

BASEc

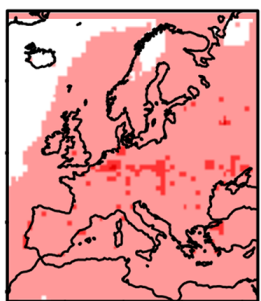

ANTSPECc

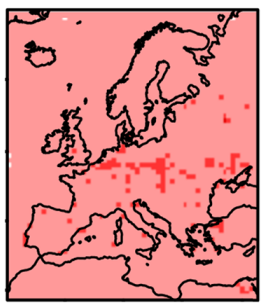

O3CHEMc

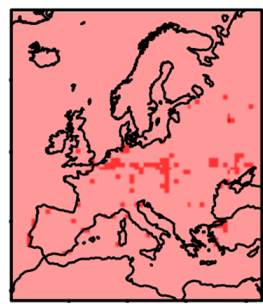

OHCHEMc

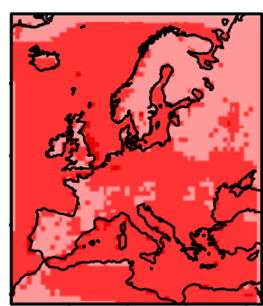

NOCHEMc

\section{$\begin{array}{llllllllll}0.05 & 0.1 & 0.2 & 0.5 & 0.98 & 1.02 & 2 & 5 & 10 & 20\end{array}$}

Figure 8. The total $\mathrm{Hg}$ deposition and the ratio of deposition in the sensitivity runs compared to BASE, ANTSPEC and BASE $\mathrm{C}$. The Hg total deposition is shown in the first row for BASE, ANTSPEC and BASE ${ }_{C}$ experiments (upper colour label), while the ratio (lower colour label) of these with relative sensitivity runs is reported over the relative column: BASE2, NOANT and NOCHEM ratios (left column) are referred to as BASE experiment, O3CHEM, OHCHEM, BRCHEM1 and BRCHEM2 (central column) ratios are referred to as ANTSPEC experiment, and $\mathrm{ANTSPEC}_{\mathrm{C}}, \mathrm{O} 3 \mathrm{CHEM}_{\mathrm{C}}, \mathrm{OHCHEM}_{\mathrm{C}}$ and $\mathrm{NOCHEM}_{\mathrm{C}}$ (right row) ratios are referred to BASE $\mathrm{C}_{\mathrm{C}}$ experiment. 
of $50: 40: 10$ (GEM : RGM : PBM; see Sect. 2.2). Gencarelli et al. (2015) compared the Hg deposition over Europe using the two most recent AMAP/UNEP inventories, showing that the lower emissions in 2010 resulted in lower simulated deposition fluxes, but the deposition reduction was proportionally less than the emission reduction within the domain. With the experiments performed it was possible to estimate the impact of $\mathrm{Hg}$ anthropogenic emission speciation on $\mathrm{Hg}$ deposition. Specifically the results of the BASE, BASE2, ANTSPEC, NOANT, BASE $E_{C}$ and ANTSPEC $_{C}$ simulations in Table 1 were compared (Figs. 8 and 10). The BASE simulation used the AMAP $\mathrm{Hg}$ emissions $\left(136.2 \mathrm{Mg} \mathrm{yr}^{-1}\right.$; GEM : RGM : PBM $65: 28: 7)$ while the BASE2 simulation used the EDGAR emissions (123.8 $\mathrm{Mg} \mathrm{yr}^{-1}$; ratio 60:32:8). The difference in emitted $\mathrm{Hg}$ over the modelling domain makes little difference in terms of the TGM concentrations and the wet deposition fluxes at the monitoring stations (see Fig. 5). However, over the whole domain the total $\mathrm{Hg}$ deposition is $\simeq 20 \%$ less using the EDGAR inventory, as shown in Table 3. The deposition pattern changes, often in areas characterised by elevated $\mathrm{Hg}$ emissions, were decreased deposition in BASE2 was found with respect to the BASE experiment (where the ratio BASE/BASE2 is $<1$ in Fig. 8). This difference is very marked over the North and Baltic seas, while it is almost negligible over the Mediterranean and Northern Atlantic. This effect is prevalently due to the difference in the vertical distribution of the emissions in the two experiments, because the total $\mathrm{Hg}$ emitted is very similar: there is only a $9 \%$ difference, contrary to Gencarelli et al. (2015), in which the same vertical distribution but different emission totals resulted only in a small change in deposition. The change in emission vertical distribution prevalently affects dry deposition processes, decreasing by $28 \%$ between the BASE and BASE2 simulations, against a $13 \%$ decrease in wet deposition (Figs. 3 and 4). In the BASE2 simulation deposition is noticeably lower over the Balkans, Carpathians and the lowlands of northern Germany, while $\mathrm{Hg}$ deposition is higher over the Skagerrak strait (which links the North and Baltic seas).

The ANTSPEC and ANTSPEC $C$ simulations isolate the role of $\mathrm{Hg}$ emission speciation. In these simulations all emissions were considered to be $\mathrm{Hg}_{(\mathrm{g})}^{0}$. Overall the simulations show an increase in the GEM concentration fields and a decrease in wet deposition, leading to improved agreement with the GEM/TGM observations in the ANTSPEC simulation (however, this is less evident in ANTSPEC $_{C}$ ). In ANTSPEC $_{C}$ improved agreement was obtained for wet deposition fluxes in some central (CZ03 and SI08) and northern (GB48, SE11 and SE14) monitoring sites. Total $\mathrm{Hg}$ deposition over the modelling domain decreased by $20 \%$ in WRF/Chem-Hg and by $22 \%$ in CMAQ. Dry deposition is particularly affected (see Table 3), with 28 and 26\% decreases in dry deposition (WRF and CMAQ respectively) compared to a 13 and $14 \%$ decrease in wet deposition.
In the ANTSPEC experiment the deposition decreases in comparison to BASE, in particular the dry decreases more than the wet. RGM and PBM deposit more rapidly than GEM and so deposit in proximity to their emission sources where the air concentrations are higher. Clearly dry deposition can occur at any time while wet deposition requires precipitation. With all $\mathrm{Hg}$ emission releases treated as GEM in ANTSPEC the dry deposition decreases most as a result of the lack of direct emissions of RGM and PBM. The areas most affected by changing the emission speciation are obviously near major sources, but also over the Aegean and the Black seas, the English Channel and the northern German coast. Considerable influences were found also over the Mediterranean, the North and Baltic seas and the rest of Europe, while very little difference is seen over the Norwegian Sea and around Iceland and only minor differences were registered at the DK01 station.

However, the contribution of anthropogenic emissions is crucial. In fact, the complete exclusion of anthropogenic emissions (the NOANT experiment) cannot reproduce the TGM concentrations and wet deposition fluxes; they are clearly underestimated, and total $\mathrm{Hg}$ deposition is only onethird of that when anthropogenic emissions are included. The NOANT experiment is a hypothetical scenario, but it allows the contribution of anthropogenic emissions to total deposition, which is roughly two-thirds, not counting the fact that natural emissions from the oceans are in part previously deposited $\mathrm{Hg}$ from anthropogenic sources. A number of policy scenarios were used during the GMOS project to estimate future trends in the anthropogenic emission of $\mathrm{Hg}$ (Pacyna et al., 2016). Pacyna et al. (2016) describe the results of modelling studies using these scenarios to assess $\mathrm{Hg}$ concentration and deposition fields, for present (2013) and future anthropogenic (2035) Hg emissions.

\subsection{Mercury oxidation}

In order to highlight the differences due to the gas-phase $\mathrm{Hg}$ oxidation mechanism employed, various simulations were performed, isolating a single oxidant in the model chemical mechanism.

The importance of the chemical reactions has been emphasised by considering the variations between BASE and NOCHEM experiments (and BASE $E_{C}$ and NOCHEM $_{C}$ ), in which no chemical interactions in the atmosphere were considered. In this experiment the RGM and PBM fields in the model domain are due prevalently to anthropogenic emissions and the influence BC on RGM and PBM is relatively minor over the model domain. Only very small changes in TGM air concentrations were found (there is slight increase $\simeq 1 \%$ in WRF, $\simeq 3 \%$ in CMAQ), while RGM and Hg deposition decreases appreciably (by $83 \%$ RGM, $25 \%$ wet and $73 \%$ dry in WRF, and 42,32 and $46 \%$ in CMAQ).

This result shows the net reduction in deposition when setting the $\mathrm{Hg}$ anthropogenic emissions to zero and provides 
a limit to the deposition due to natural emissions. With the exception of stations CZ03 and LV01, deposition is underestimated everywhere (especially in northern Europe and at FI36 and GB13 above all). Agreement within a factor of 2 was found only in some stations in central Europe (e.g. CZ03, DE02, DE09, LV01), demonstrating the importance of anthropogenic emission speciation in these particular areas with respect to $\mathrm{BC}$ and atmospheric oxidation.

A number of studies have shown the importance of $\mathrm{O}_{3}$, and the $\mathrm{OH}$ radical, as well as reactive halogen compounds in the atmospheric oxidation of $\mathrm{Hg}$, to form more readily deposited $\mathrm{Hg}^{\mathrm{II}}$ compounds (see Ariya et al., 2015, and references therein). Despite the theoretical doubts of significance of GEM oxidation under atmospheric conditions by $\mathrm{O}_{3}$ and $\mathrm{OH}$ radical, atomic $\mathrm{Br}$ is of great relevance to the atmospheric oxidation of GEM is certain (Hynes et al., 2009; Subir et al., 2011, 2012; Weiss-Penzias et al., 2015). In particular, for the $\mathrm{HgBr}^{*}$ intermediate, Dibble et al. (2012) have shown the potential importance of reactions with $\mathrm{NO}_{2}, \mathrm{HOO}$, $\mathrm{ClO}$ and $\mathrm{BrO}$.

While Subir et al. (2011) summarise the experimental and theoretical uncertainties in the calculation of the rate constants of these reactions (and also discusses the implications for CTMs), this study demonstrates the effect of individual oxidants on tropospheric $\mathrm{Hg}$ concentrations and deposition, isolating the individual contributions and comparing them with the monthly wet deposition observed at the measuring stations. Based on the ANTSPEC experiment the three main GEM oxidants have been studied individually in the experiments O3CHEM, OHCHEM and BRCHEM1 (and BRCHEM2). Compared to the BASE case the emission scenario is different, all anthropogenic emissions were considered to be GEM; thus the RGM involved in the deposition process is solely the result of atmospheric oxidation processes.

In this way it is possible to estimate the extent of individual reactions on $\mathrm{Hg}$ oxidation and its deposition. The simulations are unrealistic because these reactions most likely occur simultaneously in the atmosphere (as in BASE and ANTSPEC cases), but these experiments are a potentially useful way to provide information on the principal oxidant pathways. The O3CHEM and OHCHEM experiments (executed BC from ECHMERIT) yield quite different results; both experiments are very different than observations. The OHCHEM experiment leads to the production of only small amounts of RGM $(\backsim 40 \%$ less than ANTSPEC over the whole domain) and reduced deposition ( $\simeq 19 \%$ less than ANTSPEC). Consequently GEM concentrations are higher, $\simeq 35 \%$. As described in Subir et al. (2011) the mechanism of this reaction is unclear, and there are a number of different rate constants reported. In this study the Sommar et al. (2001) rate constant was used, but alone this oxidation pathway cannot explain the observed deposition; wet deposition fluxes are underestimated at all measuring stations. The underestimation is lowest in the southernmost stations, PT06 and LONG.
In the O3CHEM experiment only GEM oxidation by $\mathrm{O}_{3}$ is considered (Hall, 1995). The results of this experiment show very high GEM concentrations (the ratio of GEM concentrations in O3CHEM and in BASE is $\_1.33$ ) but low RGM concentrations (ratio $\simeq 0.25$ ) at ground level. Also the total deposition is underestimated (ratio $\simeq 0.24$ ). As above, this reaction alone is not sufficient to represent oxidation and the deposition of $\mathrm{Hg}$ over Europe. Individually, oxidation by $\mathrm{O}_{3}$ and $\mathrm{OH}$ does not give concentrations and fluxes comparable with the BASE case.

Using fixed $\mathrm{BC}$ (as in $\mathrm{OHCHEM}_{\mathrm{C}}$ and $\mathrm{O}_{\mathrm{CHEM}}$ ) the two simulations give very similar deposition (Fig. 8, Table 3). A decrease compared to the $\mathrm{BASE}_{\mathrm{C}}$ case was found, but the effect of $\mathrm{BC}$ is dominant and the differences in the oxidation mechanisms are not appreciable.

The BRCHEM experiments provide more interesting results: more RGM is formed at ground level, the BRCHEM1 / BASE ratio is $\simeq 1.63$ and BRCHEM 2 / BASE is $\simeq 1.70$, but the overall $\mathrm{Hg}$ wet deposition is lower than the base simulation (ratio $\simeq 0.44$ and $\simeq 0.43$ respectively). The comparison of model TGM to observations is within a factor of 2 in 16 of the 24 stations, which is the best result for the set of the oxidation mechanism experiments (O3CHEM, OHCHEM, BRCHEM). A slight overestimation was found in the stations bordering the Baltic Sea and Mediterranean Sea. In fact the atmospheric $\mathrm{Br}$ concentrations in the upper troposphere and the MBL are the subject of much scientific interest (e.g. Subir et al., 2011; Hedgecock and Pirrone, 2004; Saiz-Lopez and von Glasow, 2012; von Glasow et al., 2004). In order to analyse the effect of different $\mathrm{Br}$ input (total amount and spatial distribution), the $\mathrm{Br}$ concentration fields from the offline three-dimensional models p-TOMCAT (Yang et al., 2005) and GEOSCHEM (Parrella et al., 2012) were interpolated on to the WRF domain. For every month a daily mean profile of $\mathrm{Br}$ was obtained and used for BRCHEM1 (p-TOMCAT) and BRCHEM2 (GEOSCHEM), where a two-step GEM oxidation process which proceeds firstly by reaction with $\mathrm{Br}$ to form unstable diatomic $\mathrm{HgBr}^{*}$ was implemented (see Gencarelli et al., 2015, and references therein for details). Notable differences in the two $\mathrm{Br}$ input fields exist in the planetary boundary layer (PBL) and indeed in the whole atmospheric column. In fact, in the PBL the amount of $\mathrm{Br}$ in the BRCHEM2 experiment is $\simeq 4.5$ times greater than that in BRCHEM1, with differences ranging from a factor of 6 (in the cold months) to roughly 4 (in the summer months) over the modelling domain. These differences are also visible observing the vertical longitudinal profiles of annual mean concentrations of $\mathrm{Br}$ in Fig. 9, where $\mathrm{Br}$ in BRCHEM2 is greater than $\mathrm{Br}$ in BRCHEM1 in the first $3 \mathrm{~km}$. The $\mathrm{Br}$ in BRCHEM1 is greater than BRCHEM1 in the range between 12 and $15 \mathrm{~km}$, while at other elevations there are not such large differences.

Despite this large discrepancy in $\mathrm{Br}$ input the $\mathrm{Hg}$ deposition flux is largely unaffected. Total $\mathrm{Hg}$ deposition in BRCHEM1 is $3 \%$ greater than BRCHEM2 (2\% wet and 
$3.7 \%$ dry) due to greater concentrations of $\mathrm{Br}$ in areas with high rainfall in BRCHEM1. The spatial distribution of the deposition is different in the two experiments, especially over North Africa, the English Channel and the western Mediterranean. The RGM concentrations in the PBL are also slightly different (RGM in BRCHEM1 about is $4 \%$ lower than BRCHEM2, as shown in Fig. 8 and Table 3). Model-toobservation comparison for TGM does not change between BRCHEM1 and BRCHEM2, and the model underestimates wet deposition in both cases. In BRCHEM1 the underestimation is evident (ratio BRCHEM1 / observations $\simeq 0.77$ ) while in BRCHEM2 the model results and observations are closer (ratio $\simeq 0.90$ ). Thus, increasing the $\mathrm{Br}$ concentration gives model results closer to observations, as shown also in Shah et al. (2016), who tripled the $\mathrm{Br}$ and $\mathrm{BrO}$ concentrations in GEOS-CHEM model (with respect to Parrella et al., 2012, where an underestimation of $30 \%$ was found for $\mathrm{BrO}$ concentrations compared to the global mean obtained by satellite observations) to model the NOMADSS field campaign (Gratz et al., 2015). Differently to the Shah et al. (2016) study, RGM reduction is not implemented here; for the purposes of this paper it was necessary to standardise the experiments as far as possible. Only an aqueous-phase reduction was implemented in CMAQ, following Si and Ariya (2008).

A comparison of the annual mean RGM concentration in the first model level simulated in the various sensitivity runs is shown in Fig. 10. While BASE and BASE $\mathrm{C}_{\mathrm{C}}$ show a similar pattern, the ANTSPEC simulation (Fig. 10, first row) gives lower concentrations with no areas of elevated RGM concentrations. The ratio of the RGM concentration in the BASE2 and BASE simulations is strongly dependent on the distribution of the anthropogenic emissions, while the mean RGM concentrations in the BASE simulation are always greater then in NOANT, especially in central Europe. The opposite occurs when comparing BASE and NOCHEM, where the ratio is $\sim 1$ central Europe and $<1$ over the Mediterranean and the northern part of the domain. In the O3CHEM simulation the RGM concentrations are greater than those in ANTSPEC over the whole modelling domain, while in the OHCHEM and BRCHEM the ratio changes over the domain: in OHCHEM RGM is relatively higher over land and the Mediterranean Sea, while in BRCHEM1 RGM is lower over Mediterranean region and the Black Sea but higher over the eastern and northern parts of the domain. In the BRCHEM2 the relative decrease in RGM is found to be mostly over the eastern part of the domain and Scandinavia. Using fixed BC (the third column of Fig. 10) the simulations show decreased RGM concentrations with respect $\mathrm{BASE}_{\mathrm{C}}$, especially in the areas characterised by significant anthropogenic emissions.

\section{Conclusions}

This work was performed to analyse the influence of several processes which determine the atmospheric $\mathrm{Hg}$ cycle and
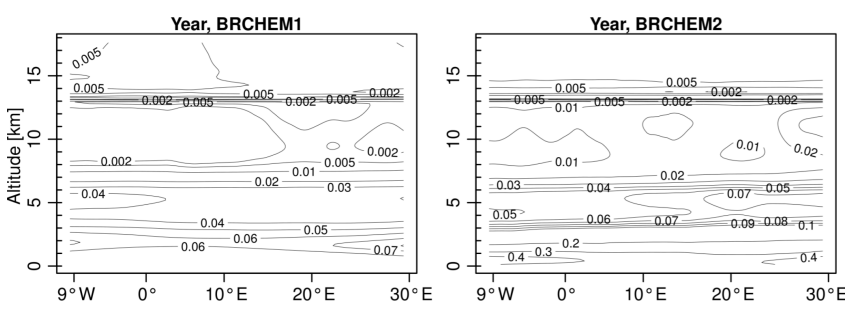

Figure 9. Vertical longitudinal profiles of Bromine annual mean concentrations (ppt) using p-TOMCAT concentrations (BRCHEM1 experiment, left panel) and GEOSCHEM concentrations (BRCHEM2 experiment, right panel).

quantify some of the uncertainties present over a European modelling domain. The output of 14 model sensitivity tests were compared between themselves and with available measurements from 28 monitoring sites. The base experiments (BASE and $\mathrm{BASE}_{\mathrm{C}}$ ) furnish model results roughly in accord with measurements of TGM concentrations and wet deposition fluxes and agree with the results of observations reported in Sprovieri et al. (2016a), with higher $\mathrm{Hg}$ deposition fluxes in the north of Europe.

In the model results the quantity, speciation and vertical profile of anthropogenic $\mathrm{Hg}$ emissions are crucial: over the whole model domain the vertical distribution of $\mathrm{Hg}$ emissions has a large influence on the $\mathrm{Hg}$ deposition fields. In addition to the areas near the principal anthropogenic emission sources, the areas of Aegean and the Black seas, the English Channel, the Skagerrak strait and the northern Germany coast are more influenced by the characteristics of European $\mathrm{Hg}$ emission speciation than they are by the total amount.

Using a reaction mechanism with GEM oxidation by only $\mathrm{O}_{3}$ or $\mathrm{OH}$ greatly underestimates the observed deposition in precipitation. Whereas using a mechanism with $\mathrm{Br}$ as the GEM oxidant produces more RGM at ground level, the overall $\mathrm{Hg}$ wet deposition is lower than the BASE simulation, which employs both $\mathrm{O}_{3}$ and $\mathrm{OH}$ in the oxidation mechanism. Nonetheless, good agreement between the model and observations was found, especially in the stations bordering the Baltic and Mediterranean seas. The Hg deposition was only slightly affected by the choice of $\mathrm{Br}$ input fields; quadrupling the $\mathrm{Br}$ air concentrations in the PBL resulted in a change of only of $3 \%$ in total deposition in accordance with the results of Shah et al. (2016) for the US.

The necessity to perform continuous measurements of speciated $\mathrm{Hg}$ in order to refine model oxidation mechanisms is clear.

Moreover, the necessity to investigate more thoroughly local influences on $\mathrm{Hg}$ emissions and deposition, as well as interactions dependent on land use and vegetation, forests, peat bogs, etc., should be investigated in future studies. 


\begin{tabular}{|l|l|l|l|l|l|l|l|l|l|l|}
\hline & & & & & & & & & \\
\hline 0.1 & 1 & 10 & 20 & 100 & 200 & $\mathrm{pg} \mathrm{m}^{-3}$
\end{tabular}

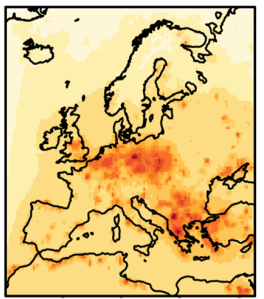

BASE

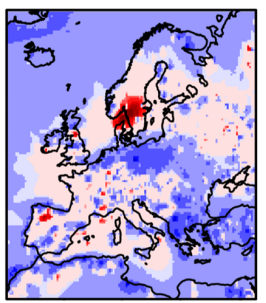

BASE2

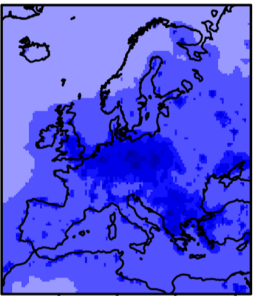

NOANT

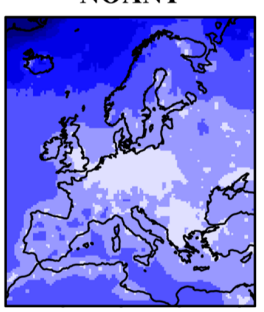

NOCHEM

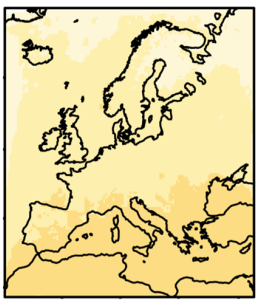

ANTSPEC
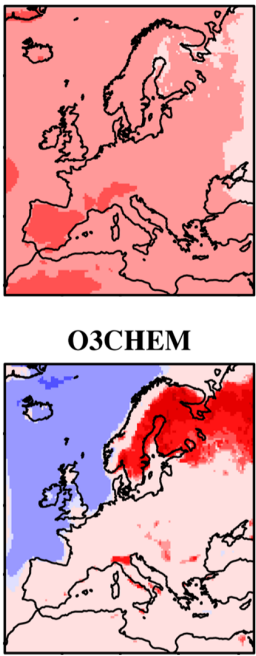

OHCHEM

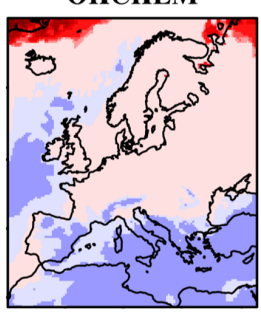

BRCHEM1

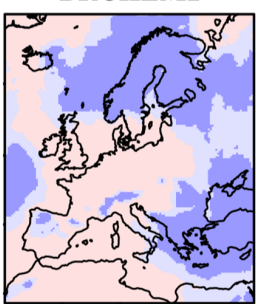

BRCHEM2

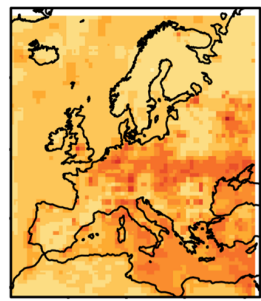

BASEc

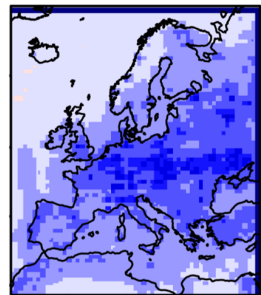

ANTSPECc

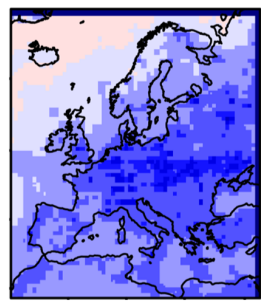

O3CHEMC

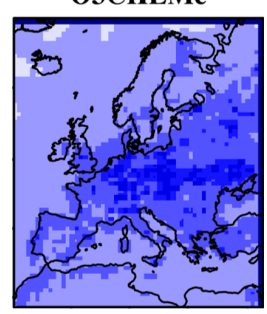

OHCHEMc

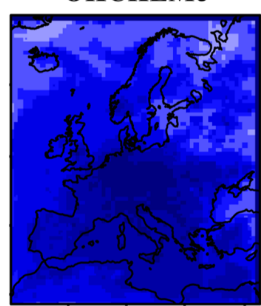

NOCHEMc

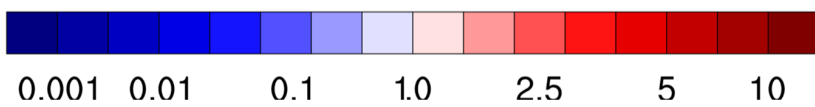

Figure 10. The annual RGM mean concentrations at ground level and the ratio of RGM in the sensitivity runs compared to BASE, ANTSPEC

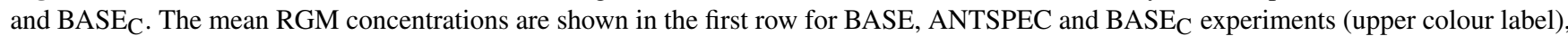
while the ratio (lower colour label) of these with the sensitivity runs is reported in the relative column: BASE2, NOANT and NOCHEM ratios (left column) are referred to the BASE experiment, O3CHEM, OHCHEM, BRCHEM1 and BRCHEM2 (central column) ratios refer to the

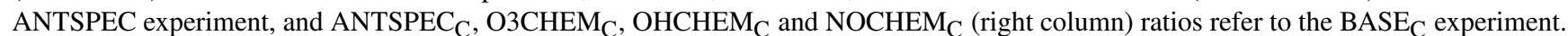




\section{Data availability}

The KPP mechanism files, a description of code modifications and the post-processing $\mathrm{R}$ and ncl scripts are available on request to the authors. Mercury data reported in this paper are available at http://www.nilu.no/projects/ ccc/emepdata.html and http://sdi.iia.cnr.it/geoint/publicpage/ GMOS/gmos_historical.zul (upon request; GMOS Database, 2017).

Acknowledgements. We are grateful to the WRF/Chem developers and to the NCAR ESL Atmospheric Chemistry Division for making the WRF/Chem and the WRF/Chem preprocessor codes freely available. We gratefully acknowledge EMEP for maintaining and making available the database of monitoring station data. We thank Noelle Eckley Selin and Shaojie Song at the Massachusetts Institute of Technology, Cambridge, for completion of GEOSCHEM $\mathrm{Br}$ input, used in the BRCHEM2 experiment. The research was performed in the framework of the EU project GMOS (FP7-265113), the National Reference Centre for Mercury (CNRM, Italy) and the STM program of the Italian CNR.

Edited by: R. Ebinghaus

Reviewed by: two anonymous referees

\section{References}

Aas, W. and Bohlin-Nizzetto, P.: Heavy metals and POP measurements 2013, Norwegian Institute for Air Research. EMEP/CCCReport, Chemical co-ordinating centre of EMEP, Kjeller, Norway, 3, 2015.

AMAP/UNEP: Technical Background Report for the Global Mercury Assessment 2013, Tech. rep., Arctic Monitoring and Assessment Programme, Oslo, Norway/UNEP ChemicalsBranch, Geneva, Switzerland, available at: http://www. unep.org/hazardoussubstances/Mercury/Informationmaterials/ ReportsandPublications/tabid/3593/Default.aspx (last access: 9 January 2017), 2013.

Amos, H. M., Jacob, D. J., Holmes, C. D., Fisher, J. A., Wang, Q., Yantosca, R. M., Corbitt, E. S., Galarneau, E., Rutter, A. P., Gustin, M. S., Steffen, A., Schauer, J. J., Graydon, J. A., Louis, V. L. St., Talbot, R. W., Edgerton, E. S., Zhang, Y., and Sunderland, E. M.: Gas-particle partitioning of atmospheric $\mathrm{Hg}$ (II) and its effect on global mercury deposition, Atmos. Chem. Phys., 12, 591-603, doi:10.5194/acp-12-591-2012, 2012.

Angot, H., Dastoor, A., De Simone, F., Gårdfeldt, K., Gencarelli, C. N., Hedgecock, I. M., Langer, S., Magand, O., Mastromonaco, M. N., Nordstrøm, C., Pfaffhuber, K. A., Pirrone, N., Ryjkov, A., Selin, N. E., Skov, H., Song, S., Sprovieri, F., Steffen, A., Toyota, K., Travnikov, O., Yang, X., and Dommergue, A.: Chemical cycling and deposition of atmospheric mercury in polar regions: review of recent measurements and comparison with models, Atmos. Chem. Phys., 16, 10735-10763, doi:10.5194/acp-1610735-2016, 2016.

Ariya, P. A., Amyot, M., Dastoor, A., Deeds, D., Feinberg, A., Kos, G., Poulain, A., Ryjkov, A., Semeniuk, K., Subir, M., and Toyota, K.: Mercury physicochemical and biogeochemical transfor- mation in the atmosphere and at atmospheric interfaces: A review and future directions, Chem. Rev., 115, 3760-3802, 2015.

Bieser, J., De Simone, F., Gencarelli, C. N., Geyer, B., Hedgecock, I. M., Matthias, V., Travnikov, O., and Weigelt, A.: A diagnostic evaluation of modeled mercury wet depositions in Europe using atmospheric speciated high-resolution observations, Environ. Sci. Pollut. R., 21, 9995-10012, doi:10.1007/s11356-014-28632, 2014.

Bieser, J., Slemr, F., Ambrose, J., Brenninkmeijer, C., Brooks, S., Dastoor, A., DeSimone, F., Ebinghaus, R., Gencarelli, C., Geyer, B., Gratz, L. E., Hedgecock, I. M., Jaffe, D., Kelley, P., Lin, C.-J., Matthias, V., Ryjkov, A., Selin, N., Song, S., Travnikov, O., Weigelt, A., Luke, W., Ren, X., Zahn, A., Yang, X., Zhu, Y., and Pirrone, N.: Multi-model study of mercury dispersion in the atmosphere: Vertical distribution of mercury species, Atmos. Chem. Phys. Discuss., doi:10.5194/acp-2016-1074, in review, 2016.

Binkowski, F. S. and Roselle, S. J.: Models-3 Community Multiscale Air Quality (CMAQ) model aerosol component 1. Model description, J. Geophys. Res.-Atmos., 108, 4183, doi:10.1029/2001JD001409, 2003.

Bullock, O. R. and Brehme, K. A.: Atmospheric mercury simulation using the CMAQ model: formulation description and analysis of wet deposition results, Atmos. Environ., 36, 2135-2146, 2002.

Bullock, O. R., Atkinson, D., Braverman, T., Civerolo, K., Dastoor, A., Davignon, D., Ku, J.-Y., Lohman, K., Myers, T. C., Park, R. J., Seigneur, C., Selin, N. E., Sistla, G., and Vijayaraghavan, K.: The North American Mercury Model Intercomparison Study (NAMMIS): Study description and modelto-model comparisons, J. Geophys. Res.-Atmos., 113, D17310, doi:10.1029/2008JD009803, 2008.

Bullock, O. R. J., Atkinson, D., Braverman, T., Civerolo, K., Dastoor, A., Davignon, D., Ku, J. Y., Lohman, K., Myers, T. C., Park, R. J., Seigneur, C., Selin, N. E., Sistla, G., and Vijayaraghavan, K.: An analysis of simulated wet deposition of mercury from the North American Mercury Model Intercomparison Study, J. Geophys. Res., 114, D08301, doi:10.1029/2008JD011224, 2009.

Byun, D. W. and Ching, J.: Science algorithms of the EPA Models3 community multiscale air quality (CMAQ) modeling system, US Environmental Protection Agency, Office of Research and Development Washington, DC, USA, 1999.

Carbone, F., Landis, M., Gencarelli, C., Naccarato, A., Sprovieri, F., De Simone, F., Hedgecock, I., and Pirrone, N.: Sea surface temperature variation linked to elemental mercury concentrations measured on Mauna Loa, Geophys. Res. Lett., 43, 7751-7757, 2016.

Chen, C. Y., Driscoll, C. T., Lambert, K. F., Mason, R. P., and Sunderland, E. M.: Connecting mercury science to policy: from sources to seafood, Rev. Environ. Health, 31, 17-20, 2016.

D’Amore, F., Bencardino, M., Cinnirella, S., Sprovieri, F., and Pirrone, N.: Data quality through a web-based QA/QC system: implementation for atmospheric mercury data from the global mercury observation system, Environ. Sci. Process. Impact., 17, 1482-1491, 2015.

De Simone, F., Gencarelli, C. N., Hedgecock, I. M., and Pirrone, N.: Global atmospheric cycle of mercury: a model study of the impact of oxidation mechanisms, Environ. Sci. Pollut. R., 21, 4110 4123, doi:10.1007/s11356-013-2451-x, 2014. 
De Simone, F., Cinnirella, S., Gencarelli, C. N., Yang, X., Hedgecock, I. M., and Pirrone, N.: Model study of global mercury deposition from biomass burning, Environ. Sci. Technol., 49, 67126721, 2015.

De Simone, F., Gencarelli, C. N., Hedgecock, I. M., and Pirrone, N.: A Modeling Comparison of Mercury Deposition from Current Anthropogenic Mercury Emission Inventories, Environ. Sci. Technol., 50, 5154-5162, doi:10.1021/acs.est.6b00691, 2016.

Dibble, T. S., Zelie, M. J., and Mao, H.: Thermodynamics of reactions of $\mathrm{ClHg}$ and $\mathrm{BrHg}$ radicals with atmospherically abundant free radicals, Atmos. Chem. Phys., 12, 10271-10279, doi:10.5194/acp-12-10271-2012, 2012.

Drewer, J., Lohila, A., Aurela, M., Laurila, T., Minkkinen, K., Penttilä, T., Dinsmore, K., McKenzie, R., Helfter, C., Flechard, C., Sutton, M. A., and Skiba, U. M.: Comparison of greenhouse gas fluxes and nitrogen budgets from an ombotrophic bog in Scotland and a minerotrophic sedge fen in Finland, Eur. J. Soil Sci., 61, 640-650, 2010.

Emmons, L. K., Walters, S., Hess, P. G., Lamarque, J.-F., Pfister, G. G., Fillmore, D., Granier, C., Guenther, A., Kinnison, D., Laepple, T., Orlando, J., Tie, X., Tyndall, G., Wiedinmyer, C., Baughcum, S. L., and Kloster, S.: Description and evaluation of the Model for Ozone and Related chemical Tracers, version 4 (MOZART-4), Geosci. Model Dev., 3, 43-67, doi:10.5194/gmd3-43-2010, 2010.

Gårdfeldt, K., Sommar, J., Ferrara, R., Ceccarini, C., Lanzillotta, E., Munthe, J., Wängberg, I., Lindqvist, O., Pirrone, N., Sprovieri, F., Pesenti, E., and Strömberg, D.: Evasion of mercury from coastal and open waters of the Atlantic Ocean and the Mediterranean Sea, Atmos. Environ., 37, 73-84, 2003.

Gbor, P. K., Wen, D., Meng, F., Yang, F., Zhang, B., and Sloan, J. J.: Improved model for mercury emission, transport and deposition, Atmos. Environ., 40, 973-983, 2006.

Gencarelli, C. N., De Simone, F., Hedgecock, I. M., Sprovieri, F., and Pirrone, N.: Development and application of a regional scale atmospheric mercury model based on WRF/Chem: a Mediterranean area investigation, Environ. Sci. Pollut. R., 21, 40954109, doi:10.1007/s11356-013-2162-3, 2014a.

Gencarelli, C. N., Hedgecock, I. M., Sprovieri, F., Schurmann, G. J., and Pirrone, N.: Importance of ship emissions to local summertime ozone production in the mediterranean marine boundary layer: a modeling study, Atmosphere, 5, 937-958, 2014b.

Gencarelli, C. N., De Simone, F., Hedgecock, I. M., Sprovieri, F., Yang, X., and Pirrone, N.: European and Mediterranean mercury modelling: Local and long-range contributions to the deposition flux, Atmos. Environ., 117, 162-168, 2015.

GMOS Database: Land-based Monitoring Sites, available at: http:// sdi.iia.cnr.it/geoint/publicpage/GMOS/gmos_historical.zul, last access: 9 January 2017.

Gratz, L., Ambrose, J., Jaffe, D., Shah, V., Jaeglé, L., Stutz, J., Festa, J., Spolaor, M., Tsai, C., Selin, N., Song, S., Zhou, X., Weinheimer, A. J., Knapp, D. J., Montzka, D. D., Flocke, F. M., Campos, T. L., Apel, E., Hornbrook, R., Blake, N. J., Hall, S., Tyndall, G. S., Reeves, M., Stechman, D., and Stell, M.: Oxidation of mercury by bromine in the subtropical Pacific free troposphere, Geophys. Res. Lett., 42, 1094-1052, doi:10.1002/2015GL066645, 2015

Grell, G. A., Peckham, S. E., Schmitz, R., McKeen, S. A., Frost, G., Skamarock, W. C., and Eder, B.: Fully coupled "online" chem- istry within the WRF model, Atmos. Environ., 39, 6957-6975, 2005.

Gustin, M. S., Amos, H. M., Huang, J., Miller, M. B., and Heidecorn, K.: Measuring and modeling mercury in the atmosphere: a critical review, Atmos. Chem. Phys., 15, 5697-5713, doi:10.5194/acp-15-5697-2015, 2015.

Hall, B.: The gas phase oxidation of elemental mercury by ozone, Water Air Soil Poll., 80, 301-315, 1995.

Hedgecock, I. M. and Pirrone, N.: Chasing Quicksilver: Modeling the Atmospheric Lifetime of $\mathrm{Hg}_{(\mathrm{g})}^{0}$ in the Marine Boundary Layer at Various Latitudes, Environ. Sci. Technol., 38, 69-76, 2004.

Holmes, C. D., Jacob, D. J., Corbitt, E. S., Mao, J., Yang, X., Talbot, R., and Slemr, F.: Global atmospheric model for mercury including oxidation by bromine atoms, Atmos. Chem. Phys., 10, 12037-12057, doi:10.5194/acp-10-12037-2010, 2010.

Horowitz, H. M., Jacob, D. J., Amos, H. M., Streets, D. G., and Sunderland, E. M.: Historical mercury releases from commercial products: Global environmental implications, Environ. Sci. Technol., 48, 10242-10250, 2014.

Hynes, A. J., Donohoue, D. L., Goodsite, M. E., and Hedgecock, I. M.: Our current understanding of major chemical and physical processes affecting mercury dynamics in the atmosphere and at the air-water/terrestrial interfaces, in: Mercury Fate and Transport in the Global Atmosphere: Emissions, Measurements and Models, edited by: Pirrone, N. and Mason, R. P., chap. 14 Springer, 427-457, doi:10.1007/978-0-387-93958-2_14, 2009.

Jung, G., Hedgecock, I. M., and Pirrone, N.: ECHMERIT V1.0 - a new global fully coupled mercury-chemistry and transport model, Geosci. Model Dev., 2, 175-195, doi:10.5194/gmd-2175-2009, 2009

Kos, G., Ryzhkov, A., Dastoor, A., Narayan, J., Steffen, A., Ariya, P. A., and Zhang, L.: Evaluation of discrepancy between measured and modelled oxidized mercury species, Atmos. Chem. Phys., 13, 4839-4863, doi:10.5194/acp-13-4839-2013, 2013.

Landis, M. S., Stevens, R. K., Schaedlich, F., and Prestbo, E. M.: Development and characterization of an annular denuder methodology for the measurement of divalent inorganic reactive gaseous mercury in ambient air, Environ. Sci. Technol., 36, 3000-3009, 2002.

Lin, C.-J., Pongprueksa, P., Lindberg, S. E., Pehkonen, S. O., Byun, D., and Jang, C.: Scientific uncertainties in atmospheric mercury models I: Model science evaluation, Atmos. Environ., 40, 29112928, 2006.

Lin, X. and Tao, Y.: A numerical modelling study on regional mercury budget for eastern North America, Atmos. Chem. Phys., 3, 535-548, doi:10.5194/acp-3-535-2003, 2003.

Liu, X.-H. and Zhang, Y.: Understanding of the formation mechanisms of ozone and particulate matter at a fine scale over the southeastern US: Process analyses and responses to future-year emissions, Atmos. Environ., 74, 259-276, 2013.

Muntean, M., Janssens-Maenhout, G., Song, S., Selin, N. E., Olivier, J. G., Guizzardi, D., Maas, R., and Dentener, F.: Trend analysis from 1970 to 2008 and model evaluation of EDGARv4 global gridded anthropogenic mercury emissions, Sci. Total Environ., 494, 337-350, 2014.

Neu, J. L. and Prather, M. J.: Toward a more physical representation of precipitation scavenging in global chemistry models: cloud overlap and ice physics and their impact on tropospheric ozone, 
Atmos. Chem. Phys., 12, 3289-3310, doi:10.5194/acp-12-32892012, 2012.

Oken, E., Choi, A., Karagas, M., Mariën, K., Rheinberger, C., Schoeny, R., Sunderland, E., and Korrick, S.: Which fish should I eat? Perspectives influencing fish consumption choices, Environ. Health Persp., 120, 790-798, 2012.

Pacyna, J. M., Travnikov, O., De Simone, F., Hedgecock, I. M., Sundseth, K., Pacyna, E. G., Steenhuisen, F., Pirrone, N., Munthe, J., and Kindbom, K.: Current and future levels of mercury atmospheric pollution on a global scale, Atmos. Chem. Phys., 16, 12495-12511, doi:10.5194/acp-16-12495-2016, 2016.

Parrella, J. P., Jacob, D. J., Liang, Q., Zhang, Y., Mickley, L. J., Miller, B., Evans, M. J., Yang, X., Pyle, J. A., Theys, N., and Van Roozendael, M.: Tropospheric bromine chemistry: implications for present and pre-industrial ozone and mercury, Atmos. Chem. Phys., 12, 6723-6740, doi:10.5194/acp-12-6723-2012, 2012.

Rockel, B., Will, A., and Hense, A.: The regional climate model COSMO-CLM (CCLM), Meteorol. Z., 17, 347-348, 2008.

Ryaboshapko, A., Bullock Jr., O. R., Christensen, J., Cohen, M., Dastoor, A., Ilyin, I., Petersen, G., Syrakov, D., Travnikov, O., Artz, R. S., Davignon, D., Draxler, R. R., Munthe, J., and Pacyna, J.: Intercomparison study of atmospheric mercury models: 2. Modelling results vs. long-term observations and comparison of country deposition budgets, Sci. Total Environ., 377, 319-333, 2007.

Saiz-Lopez, A. and von Glasow, R.: Reactive halogen chemistry in the troposphere, Chem. Soc. Rev., 41, 6448-6472, 2012.

Salzmann, M. and Lawrence, M. G.: Automatic coding of chemistry solvers in WRF-Chem using KPP, in: 7th WRF User's Workshop, Boulder, Colorado, USA, 2006.

Sandu, A. and Sander, R.: Technical note: Simulating chemical systems in Fortran90 and Matlab with the Kinetic PreProcessor KPP-2.1, Atmos. Chem. Phys., 6, 187-195, doi:10.5194/acp-6187-2006, 2006.

Sarwar, G., Luecken, D., Yarwood, G., Whitten, G. Z., and Carter, W. P.: Impact of an updated carbon bond mechanism on predictions from the CMAQ modeling system: Preliminary assessment, J. Appl. Meteorol. Clim., 47, 3-14, 2008.

Selin, N. E., Jacob, D. J., Yantosca, R. M., Strode, S., Jaeglé, L., and Sunderland, E. M.: Global 3-D land-ocean-atmosphere model for mercury: Present-day versus preindustrial cycles and anthropogenic enrichment factors for deposition, Global Biogeochem. Cy., 22, GB2011, doi:10.1146/annurev.environ.051308.084314, 2008.

Shah, V., Jaeglé, L., Gratz, L. E., Ambrose, J. L., Jaffe, D. A., Selin, N. E., Song, S., Campos, T. L., Flocke, F. M., Reeves, M., Stechman, D., Stell, M., Festa, J., Stutz, J., Weinheimer, A. J., Knapp, D. J., Montzka, D. D., Tyndall, G. S., Apel, E. C., Hornbrook, R. S., Hills, A. J., Riemer, D. D., Blake, N. J., Cantrell, C. A., and Mauldin III, R. L.: Origin of oxidized mercury in the summertime free troposphere over the southeastern US, Atmos. Chem. Phys., 16, 1511-1530, doi:10.5194/acp-16-1511-2016, 2016.

Si, L. and Ariya, P. A.: Reduction of Oxidized Mercury Species by Dicarboxylic Acids (C2-C4): Kinetic and Product Studies, Environ. Sci. Technol., 42, 5150-5155, 2008.

Siudek, P., Frankowski, M., and Siepak, J.: Atmospheric particulate mercury at the urban and forest sites in central Poland, Environ. Sci. Pollut. R., 23, 2341-2352, 2016.
Sommar, J., Gårdfeldt, K., Strömberg, D., and Feng, X.: A kinetic study of the gas-phase reaction between the hydroxyl radical and atomic mercury, Atmos. Environ., 35, 3049-3054, doi:10.1016/S1352-2310(01)00108-X, 2001.

Sprovieri, F., Pirrone, N., Ebinghaus, R., Kock, H., and Dommergue, A.: A review of worldwide atmospheric mercury measurements, Atmos. Chem. Phys., 10, 8245-8265, doi:10.5194/acp10-8245-2010, 2010.

Sprovieri, F., Pirrone, N., Bencardino, M., D’Amore, F., Angot, H., Barbante, C., Brunke, E.-G., Arcega-Cabrera, F., Cairns, W., Comero, S., Diéguez, M. D. C., Dommergue, A., Ebinghaus, R., Feng, X. B., Fu, X., Garcia, P. E., Gawlik, B. M., Hageström, U., Hansson, K., Horvat, M., Kotnik, J., Labuschagne, C., Magand, O., Martin, L., Mashyanov, N., Mkololo, T., Munthe, J., Obolkin, V., Islas, M. R., Sena, F., Somerset, V., Spandow, P., Vardè, M., Walters, C., Wängberg, I., Weigelt, A., Yang, X., and Zhang, H.: Five-year records of Total Mercury Deposition flux at GMOS sites in the Northern and Southern Hemispheres, Atmos. Chem. Phys. Discuss., doi:10.5194/acp-2016-517, in review, 2016a.

Sprovieri, F., Pirrone, N., Bencardino, M., D’Amore, F., Carbone, F., Cinnirella, S., Mannarino, V., Landis, M., Ebinghaus, R., Weigelt, A., Brunke, E.-G., Labuschagne, C., Martin, L., Munthe, J., Wängberg, I., Artaxo, P., Morais, F., Barbosa, H. D. M. J., Brito, J., Cairns, W., Barbante, C., Diéguez, M. D. C., Garcia, P. E., Dommergue, A., Angot, H., Magand, O., Skov, H., Horvat, M., Kotnik, J., Read, K. A., Neves, L. M., Gawlik, B. M., Sena, F., Mashyanov, N., Obolkin, V., Wip, D., Feng, X. B., Zhang, H., Fu, X., Ramachandran, R., Cossa, D., Knoery, J., Marusczak, N., Nerentorp, M., and Norstrom, C.: Atmospheric mercury concentrations observed at ground-based monitoring sites globally distributed in the framework of the GMOS network, Atmos. Chem. Phys., 16, 11915-11935, doi:10.5194/acp16-11915-2016, 2016b.

Storelli, M. M., Barone, G., Cuttone, G., Giungato, D., and Garofalo, R.: Occurrence of toxic metals $(\mathrm{Hg}, \mathrm{Cd}$ and $\mathrm{Pb})$ in fresh and canned tuna: Public health implications, Food Chem. Toxicol., 48, 3167-3170, doi:10.1016/j.fct.2010.08.013, 2010.

Subir, M., Ariya, P. A., and Dastoor, A. P.: A review of uncertainties in atmospheric modeling of mercury chemistry I. Uncertainties in existing kinetic parameters - Fundamental limitations and the importance of heterogeneous chemistry, Atmos. Environ., 45, 5664-5676, 2011.

Subir, M., Ariya, P. A., and Dastoor, A. P.: A review of the sources of uncertainties in atmospheric mercury modeling II. Mercury surface and heterogeneous chemistry - A missing link, Atmos. Environ., 46, 1-10, 2012.

Travnikov, O., Jonson, J., Andersen, A., Gauss, M., Gusev, A., Rozovskaya, O., Simpson, D., Sokovyh, V., Valiyaveetil, S., and Wind, P.: Development of the EMEP global modelling framework: Progress report. EMEP/MSC-E Technical Report 7/2009, Tech. rep., Meteorological Synthesizing Centre - East, Moscow, Russia, 2009.

Travnikov, O., C.-J., L., Dastoor, A., Bullock, O., Hedgecock, I. M., Holmes, C., Ilyin, I., Jaegle, L., Jung, G., Pan, L., Pongprueksa, P., Ryzhkov, A., Seigneur, C., and Skov, H.: Hemispheric Treansport of Air Pollution, Part B: Mercury, chap. chap. 4: Global and regional modeling, 97-144, United Nations, New York, USA, Geneva, Switzerland, 2010. 
Travnikov, O., Angot, H., Artaxo, P., Bencardino, M., Bieser, J., D’Amore, F., Dastoor, A., De Simone, F., Diéguez, M. D. C., Dommergue, A., Ebinghaus, R., Feng, X. B., Gencarelli, C. N., Hedgecock, I. M., Magand, O., Martin, L., Matthias, V., Mashyanov, N., Pirrone, N., Ramachandran, R., Read, K. A., Ryjkov, A., Selin, N. E., Sena, F., Song, S., Sprovieri, F., Wip, D., Wängberg, I., and Yang, X.: Multi-model study of mercury dispersion in the atmosphere: Atmospheric processes and model evaluation, Atmos. Chem. Phys. Discuss., doi:10.5194/acp-2016-924, in review, 2016.

von Glasow, R., von Kuhlmann, R., Lawrence, M. G., Platt, U., and Crutzen, P. J.: Impact of reactive bromine chemistry in the troposphere, Atmos. Chem. Phys., 4, 2481-2497, doi:10.5194/acp-42481-2004, 2004.

Wang, J., Feng, X., Anderson, C. W., Xing, Y., and Shang, L.: Remediation of mercury contaminated sites - A review, J. Hazard. Mater., 221, 1-18, 2012.

Wanninkhof, R.: Relationship Between Wind Speed and Gas Exchange Over the Ocean, J. Geophys. Res.-Atmos., 97, 73737382, doi:10.1029/92JC00188, 1992.

Weigelt, A., Ebinghaus, R., Pirrone, N., Bieser, J., Bödewadt, J., Esposito, G., Slemr, F., van Velthoven, P. F. J., Zahn, A., and Ziereis, H.: Tropospheric mercury vertical profiles between 500 and $10000 \mathrm{~m}$ in central Europe, Atmos. Chem. Phys., 16, 41354146, doi:10.5194/acp-16-4135-2016, 2016.

Weiss-Penzias, P., Amos, H. M., Selin, N. E., Gustin, M. S., Jaffe, D. A., Obrist, D., Sheu, G.-R., and Giang, A.: Use of a global model to understand speciated atmospheric mercury observations at five high-elevation sites, Atmos. Chem. Phys., 15, 11611173, doi:10.5194/acp-15-1161-2015, 2015.
Wesely, M.: Parameterization of surface resistances to gaseous dry deposition in regional-scale numerical models, Atmos. Environ., 23, 1293-1304, doi:10.1016/0004-6981(89)90153-4, 1989.

Yang, X., Cox, R. A., Warwick, N. J., Pyle, J. A., Carver, G. D., O'Connor, F. M., and Savage, N. H.: Tropospheric bromine chemistry and its impacts on ozone: A model study, J. Geophys. Res.-Atmos., 110, 1984-2012, 2005.

Yang, X., Pyle, J. A., Cox, R. A., Theys, N., and Van Roozendael, M.: Snow-sourced bromine and its implications for polar tropospheric ozone, Atmos. Chem. Phys., 10, 7763-7773, doi:10.5194/acp-10-7763-2010, 2010.

Žagar, D., Sirnik, N., Četina, M., Horvat, M., Kotnik, J., Ogrinc, N., Hedgecock, I. M., Cinnirella, S., De Simone, F., Gencarelli, C. N., and Pirrone, N.: Mercury in the Mediterranean. Part 2: processes and mass balance, Environ. Sci. Pollut. R., 21, 40814094, doi:10.1007/s11356-013-2055-5, 2013.

Zhang, Y., Jaeglé, L., van Donkelaar, A., Martin, R. V., Holmes, C. D., Amos, H. M., Wang, Q., Talbot, R., Artz, R., Brooks, S., Luke, W., Holsen, T. M., Felton, D., Miller, E. K., Perry, K. D., Schmeltz, D., Steffen, A., Tordon, R., Weiss-Penzias, P., and Zsolway, R.: Nested-grid simulation of mercury over North America, Atmos. Chem. Phys., 12, 6095-6111, doi:10.5194/acp12-6095-2012, 2012.

Zhu, J., Wang, T., Bieser, J., and Matthias, V.: Source attribution and process analysis for atmospheric mercury in eastern China simulated by CMAQ-Hg, Atmos. Chem. Phys., 15, 8767-8779, doi:10.5194/acp-15-8767-2015, 2015. 